\title{
Galbács Péter*
}

\section{A racionális várakozások elméletének fogalmi inkonzisztenciájáról}

\begin{abstract}
A tanulmányban a racionális várakozások elméletét alkotó feltételezések és következtetések ellenmondásait vizsgáljuk meg. Érvelésünk annak belátására irányul, hogy a későbbi újklasszikus elmélet szempontjából meghatározó fontosságú tételek érvelési zavarokat okoznak, s ezért a torzítatlanság követelménye átgondolást igényel. A racionális várakozások elmélete mégsem haszontalan elméleti konstruktum, hiszen a hipotézis határainak megfelelö kijelölésével kiváló elméleti igazolást nyújthatunk az inflációs célkövetési rezsimek müködőképességére vonatkozóan. Ha a túlzó előfeltevéseket elengedjük, amellyel helyet szorítunk a várakozások vezetésére képes és arra hivatott monetáris hatóságnak, a Muth által adott hipotézis mérsékelt változatához jutunk ugyan, ám e koncepció némely következménye konzisztens lesz az eredeti (erös) definíció - egyébként tarthatatlannak tünő feltételeken nyugvó - feltételezéseivel.

Journal of Economic Literature (JEL) kód: B2, E5.

Kulcsszavak: racionális várakozások, monetarizmus, újklasszikus makroökonómia, inflációs célkövetési rendszer.
\end{abstract}

\section{Bevezető megjegyzések}

Kétség sem fér hozzá, hogy a racionális várakozások elmélete, illetve az azt kidolgozó újklasszikus makroökonómia sok fejtörést okozott a közgazdászoknak, s az elmélet helye mind a mai napig nem tisztázódott megnyugtató módon. Annak ellenére (vagy inkább azzal együtt), hogy a racionális várakozások elmélete a folyamatos piacmegtisztulás paradigmájával kiegészülve az aktivista gazdaság- és monetáris politika eleve elrendelt kudarcát hirdeti, ${ }^{1}$ az elmélet szerves módon beépült a mai modernnek nevezett politikai ajánlásokba (gondoljunk csak Finn E. Kydland és Edward C. Prescott Nobel-díjjal jutalmazott téziseire). Logikailag világosan levezethető, hogy a racionális várakozások elmélete (illetve annak teljesülése) meghatározó fontosságú az inflációs célkövetési rendszerek hatásmechanizmusának magyarázatához (vö. Harasztosi 2004) - legalábbis belátható, hogy teljesül a Muth által felvetett kritérium, amely szerint a releváns elmélet és a gazdasági szereplők várakozásai

* Galbács Péter a Miskolci Egyetem Gazdaságtudományi Karának doktori ösztöndíjasa. E-mail: petergalbacs@chello. hu. A szerző hálás köszönettel tartozik Dr. Bugnics Richárdnak, Dr. Vigvári Andrásnak, Dr. Vígh Lászlónak, illetve két anonim lektorának a tanulmány korábbi változatához füzött kritikai megjegyzéseikért. Minden további hiba a szerzőt terheli.

1 A racionális várakozások nem egyensúlyi környezetben történő müködésének következményeiről, s az anticiklikus gazdaságpolitika anticipált akciók melletti hatásosságáról lásd pl. (Fischer 1977). 
egybeesnek, még ha a működés ténye - ahogy látni fogjuk - a muth-i definícióból nem is következik. S mégis, egyre nyilvánvalóbbá válik, hogy terjedelmes lyuk tátong közgazdasági tudásunk szövetén. A maga nyers formájában a racionális várakozások elmélete nem vet számot a költségek hatásával (vö. Erdős 1998:45), az infláció a klasszikus szövegek szerint már kizárólag a várakozásoktól függ. A várakozások racionalitására a jegybanki politika is számít - ugyanakkor a jegybanki inflációs modellek az árak alakulását teljes egészében a költségekből vezetik le (ezzel összefüggésben az egyik legfontosabb eredményhez lásd Várpalotai 2003). Ha az árak magyarázatához (ökonometriai szempontból) elegendőek a költségek (vagyis a keynesi alapok meghaladása - legalábbis ezen a téren - gyakorlatilag szükségtelen), akkor az egyre szélesebb körben hivatkozott várakozások hol jutnak szerephez? E kérdés megnyugtató megválaszolásához mai tudásunk bizonyosan hiányos. ${ }^{2}$

Az inflációs célkövetési rendszer működése, illetve annak sajátságai még egy fontos momentumra felhívják a figyelmet. A monetarizmus (amelyhez radikális szárnyként végső soron a racionális várakozások elméletét megfogalmazó új-klasszikus csoport is sorolható3) saját elméletét egy nagyon erős megkötés alkalmazása mellett fogalmazta meg - s e vonás nagyban korlátozta az elmélet relevanciáját. Úgy tünhet tehát, hogy a monetarista elmélet kizárólag ott (azon makrogazdasági rendszerek leírására) alkalmazható, ahol a központi bank a pénzmennyiség befolyásolására fogalmazza meg közbülső célját. A pénzmennyiség operatív célként való alkalmazása ma már semmiképp sem tekinthető általánosnak (s korábban sem volt túlzottan sikeres, ráadásul puszta kivitelezhetősége is problémás a pénzügyi innováció elöretörésének köszönhetően ${ }^{4}$ ). Mindebből arra lehet következtetni - ahogyan erre egyébként néhányan hajlamosak is -, hogy a monetarista elmélettel napjainkban már szükségtelen számot vetni. ${ }^{5} \mathrm{~A}$ helyzet azonban merőben más. A modern, az inflációs célkövetésre épülő jegybanki politika ma (a korábbi állapotokhoz viszonyítva) sokkal inkább tart a kezében olyan eszközt, amelynek alkalmazásával megfelelö hatékonysággal képes befolyásolni az árszínvonalat. Erösen leegyszerüsítve tehát azt is mondhatnánk, hogy ami a pénzmennyiség befolyásolásával nem sikerült, ma valóra válhat az inflációs célkövetési rezsimekben. A monetarizmust tehát nem elfelejteni kell, hanem ismét napirendre venni, és

\footnotetext{
2 A várakozások árdinamikában betöltött szerepe hosszú évtizedek óta a magaselmélet legfontosabb kérdései közé tartozott, még ha a neki tulajdonitott jelentöség időnként meg is fakult. Mises például már 1912-ben felhivta a figyelmet arra, hogy egyes esetekben (például hiperinfláció mellett) az árfolyamatok elszakadhatnak a pénzmennyiség által jelentett alaptól, s a pénz értékének alakulását ekkor már a várakozások határozzák meg (vö. Mises 1981:251-262). A későbbi elméleti fejlódés szempontjából igen kellemetlen ez a megfigyelés, amelyröl a közgazdászok igyekeztek nagyvonalúan meg is feledkezni, hiszen ebböl a mennyiségi egyenlet érvénytelenitése következik (hiszen végső soron nem a pénzmennyiség fogja meghatározni az árszínvonalat). Bármilyen furcsa is, a várakozások hangsúlyozása közben az ortodox monetarista és újklasszikus közgazdászok egyetlen percre sem helyezték hatályon kívül a nyers mennyiségi egyenletet - a várakozások szerepe kizárólag a tévedések területére korlátozódott, s az árszínvonal és a pénzmennyiség közötti következetes összefüggés mintegy ex machina müködött.

${ }^{3}$ Ez az ítélet koránt sem olyan egyértelmü, mint amennyire vonzó és tetszetös. Egyes szerzők határozottan állítják, hogy az újklasszikus csoport a monetarista iskolához sorolandó (pl. Mátyás 1984), míg mások szerint az ortodox monetarizmus inkább Marshall, az újklasszikus makroökonómia pedig Walras útját követi (Hoover 1990). Az értékelést némiképp segítheti, ha hiszünk Milton Friedmannek, aki például a munkanélküliség természetes rátája kapcsán a walrasi egyensúlyra hivatkozik (M. Friedman 1986:229).

${ }^{4}$ E pénzügyi innováció sajátos aspektusairól és a megvalósulás instrumentumairól lásd (Vigvári 2004: 78-79). Mindezzel kapcsolatban elegendő, ha az egyre inkább teret nyerő e-money példájára gondolunk, amely a vásárlóerö közvetítésére alkalmas pénzállománynak a monetáris hatóság által gyakorlatilag ellenörizhetetlen elemét alkotja.

${ }^{5}$ Fel kell hívni a figyelmet, hogy a REH és az újklasszikus elmélet nem szinonim fogalmak; a REH - leválva az újklaszszikus makroökonómia elméletéröl - önálló életre kelt. Akárhogyan is nézzük, a REH mégis ezer szállal kapcsolódik a monetarista közgazdaságtanhoz (ezzel kapcsolatban lásd az ortodox monetarizmus és az újklasszikus elmélet gyökereiról elmondottakat is).
} 
egy újabb (potenciális) monetáris forradalom keretei között átgondolni, melyek az elmélet ma is releváns (vagy helyesebben fogalmazva: melyek az elmélet ma újból relevánssá tehetö) elemei - illetve megvizsgálni, hogy a REH (Rational Expectations Hypothesis - racionális várakozási hipotézis) mellett milyen relevanciája van például az árak (közvetlen) jegybanki szabályozásának, ami végső soron egy, a mennyiségi egyenletre emlékeztető szabály életbe lépését jelentheti. Egy elmélet sohasem monolit tömeg, sokkal inkább olyan mozaik, amelynek darabjait feltételezések és következmények kötik össze. Ezt a sajátságot természetesen a közgazdasági elmélet is felismerte, hiszen ennek híján ma aligha lehetne szó a racionális várakozások elméletéről anélkül, hogy a teljes monetarista elméleti rendszert (bármi legyen is az) meg ne próbálnák ránk erőltetni.

E rövid tanulmányban - nem kertelünk - e feladatnak talán legegyszerübben kivitelezhető elemét igyekszünk megragadni, és a monetarizmus talán legéletképesebb, ugyanakkor legvitatottabb elemének, a racionális várakozási hipotézis belső ellenmondásaira kívánjuk felhívni a figyelmet - de természetesen nem feledkezünk meg az elmélet azon vonzó tulajdonságairól sem, amelyek sikerét okozták. Ennek megfelelően elsőként egy koherens képet igyekszünk rajzolni arról, amit racionális várakozási elméletnek neveznek - s talán belátjuk majd, hogy ez cseppet sem egyszerü feladat, hiszen a hipotézis követői sem alkotnak egységes csoportot a feltételezéseket és a következményeket illetően. ${ }^{6}$ Figyelmünk középpontjában ezért azok a (gyakorlati) nehézségek állnak, amelyek kétségessé teszik a $R E H$ erős hipotézisének plauzibilitását. Ezen problémák számbevétele révén eljutunk majd a $R E H$ erős hipotézisének egy alternatív (mérsékelt) formájához, amelyben elismerjük a gazdasági szereplők által készített egyedi becslések torzítottságát, alapul véve a becslések aszimptotikus torzítatlanságát, s egy központi helyzetben lévő intézmény (a jegybank) bevezetésével végső soron biztosítjuk majd, hogy a releváns (kvázi-releváns) modell és a gazdasági szereplők várakozásai egybeessenek, teljesítve a $R E H$ erős hipotézisének alapvető követelményét, igaz, alternatív müködési mechanizmus révén.

\section{A racionalitás fogalmai}

A REH irodalmában - gondolva itt nemcsak az újklasszikus iskolára, hanem mindazon elméleti csoportokra, amelyek mondanivalójuk megfogalmazásakor a várakozások (valamilyen szintü) racionalitását feltételezték - egyetlen mértékadó szerző sem müködött az utóbbi néhány évtizedben anélkül, hogy ne hivatkozott volna John F. Muth 1961-ben közreadott, a későbbi elméleti fejlődés szempontjából meghatározó fontosságú tanulmányára (Muth 1961) (a gondolat eredetileg merőben más közegben bukkant fel, mint amivel

\footnotetext{
${ }^{6}$ Arról sem szabad megfeledkezni, hogy a REH kidolgozói és alkalmazói talán minden korábbi iskolánál jobban támaszkodtak a matematikai apparátus igénybevételére. Ezért öket kritika semmiképp sem illetheti, hiszen a formulák erdeje nagyban segíti hipotéziseik és tételeik interpretációját. Ugyanakkor az is igaz, hogy a modelljeik alapján levont következtetések a szó legszorosabb értelmében vett következmények, vagyis közvetlenül az egyenletek felírási módjából következnek - az általánosítások levonása tehát időnként nehézkes.
} 
kapcsolatban egy évtizeddel később Robert E. Lucas alkalmazta ${ }^{7}$ ). Muth sokat idézett definíciója szerint a vállalatok ${ }^{8}$ várakozásainak eloszlása (vagy pedig, általánosabban fogalmazva, a kimenetek szubjektív valószínüség-eloszlása) az elmélet által adott jóslás (illetve a kimenetek „objektív” valószínűség-eloszlása) körül alakul, ugyanazon információs készlet esetében. Vagyis a racionális piaci szereplők arra számítanak, aminek bekövetkezése a legvalószínűbb (s egyben ez lesz az a kritérium is, amely alapján az elóállított várakozások racionalitásáról dönthetünk). Muth néhány sorral később elméletének értelmezését is igyekszik megadni - az általa kiemelt jellegzetességek közül talán legfontosabb az a kitétel, amely szerint az elmondottak értelmében egy nyilvánosságra hozott elörejelzés nem fog érdemi hatást gyakorolni a vizsgált makrogazdasági rendszer müködésére, hacsak e jóslat nem bennfentes (vagyis a gazdasági szereplők számára nem hozzáférhető) információkon alapul. ${ }^{9}$ A Muth nyomán adott interpretációk kiemelik, hogy a várakozásformálódás ekként történő leírása egyébként nem jelenti a piaci szereplők tökéletes elörelátásának, vagy teljes körü információk birtoklásának feltételezését - mindössze arról van szó, hogy az aktorok igyekeznek az ismereteket a lehető leghatékonyabb módon felhasználni, s arra számítanak, ami a legvalószínűbb, ${ }^{10}$ várakozásaik kialakításakor pedig erőteljesen támaszkodnak a releváns gazdaságelmélet eredményeire (Pete 2001:135). Mellesleg a REH és a tökéletes elörelátás feltételezésének ( $P F H$ - Perfect Foresight Hypothesis) viszonya sokszor tisztázatlanul bukkan fel - időnként (és egyébként tévesen) a két modell egymás szinonimája (vö. Bryant 1983). A helyes értelmezéshez mindenképpen szükséges a determinisztikus és a sztochasz-

\footnotetext{
7 Meggyőző érvekkel alátámasztható, hogy a racionális várakozások feltevése eredetileg nem Muth-nál bukkant fel elsőként. Jan Tinbergen 1932-ben publikált tanulmányában (Ein Problem der Dynamik) egy olyan modellt épít fel, amely koncepcióját tekintve sokban emlékeztet Muth három évtizeddel későbbi munkájára - bár természetesen jelentős különbségek mutatkoznak. Tinbergen tudatában volt annak, hogy a jövőt övező bizonytalanság miatt az aktorok várakozásokat formálnak (bár az egyszerüség kedvéért modelljében azt feltételezte, hogy a gazdasági szereplők között nincsenek véleménykülönbségek). E várakozások racionálisak (vernünftig), ha azt tételezhetjük fel róluk, hogy konzisztensek a gazdasági összefüggésekkel, s bizonyos esetekben e várakozások fel is cserélhetők gazdaságelméleti következtetésekkel - s ez a meghatározás rímel a Muth által adott definícióra, valamint a releváns gazdaságelmélet koncepciójára (vö. Keuzenkamp 1991).

8 Talán nem lenne túlzás, ha e megállapítást a gazdasági szereplők összességére is általánosítanánk.

9 A diszkrecionális monetáris politika hatástalanságához tehát nem elegendőek a racionális módon képzett várakozások, ahhoz bizonyos a ragadósság kizárására, illetve a monetáris politika és az egyéb gazdasági szereplők információnak azonos állományának követelményére is szükség van (vö. Dickinson et al. 1982). Érvelésünk a későbbiek során éppen annak beláttatására irányul, hogy Muth tételének ezen kiegészítő - és a magaselmélet által teljesen elhanyagolt - megjegyzése (csakis bennfentes információk képesek a gazdasági szereplők várakozásainak módosítására) valójában kritikus fontosságú az elmélet müködése szempontjából.

10 Megtévesztő lehet, hiszen a későbbiekben úgy fogunk beszélni a várakozásokról, mintha azok diszkrét pontok volnának - holott nyilvánvaló, hogy a várakozások sokkal inkább valószínüség-eloszlást alkotnak. E diszkrét pontokat tekintsük egyszerü pontbecsléseknek.
} 
tikus modellek határozott megkülönböztetése, hiszen a $R E H$ az elöbbiek esetében valóban azonosítható a tökéletes előrelátás feltételezésével ${ }^{11}$ (Barro - Fischer 1976).

Mielőtt továbblépnénk, el kell időznünk a racionalitás, illetve a racionális várakozások fogalmánál. Mindenekelőtt ki kell térnünk arra a momentumra, amelyre szintén Muth hívja fel a figyelmet. Tanulmányából egyértelműen kiderül, hogy a racionális módon képzett várakozás (vagy másként: a várakozások racionális képzése) sokkal inkább kognitív aktus, mintsem matematikai eszközökkel felírható várakozási operátor. Legyen szó akár egy egyszerű extrapolatív (vagy annak puszta algebrai származékairól, a naiv, illetve a regresszív ${ }^{12}$ modellről), akár egy adaptív sémáról,$^{13}$ differenciaegyenletek segítségével a várakozásképzési folyamat jól felírható. Muth tanulmánya viszont rávilágít arra, hogy a racionalitás (a várakozások racionalitása) valami egészen más minőség, és e kategória nem a várakozások formálódásának eredményeként előálló számadat képzési módjára (annak eljárására), sokkal inkább a felhasznált információkhoz való viszonyra vonatkozik (muth-i értelemben racionálisnak minősített előrejelzés számos, a helyzet által indokolt és lehetővé tett módon képezhető). A REH legenyhébb megfogalmazása nem állít mást (erősebb definíciói ennél persze jóval messzebbre mennek), mint hogy a gazdasági szereplők várakozásaik kialakításakor nemcsak a kérdéses változó múltbeli értékeit veszik számba, hanem minden olyan információt is, amely a historikus adatokon kívül rendelkezésre áll a kérdéses változót befolyásoló faktorokra vonatkozóan. ${ }^{14}$ Egy szemléletes hasonlattal élve, a brazíliai kávé jövőbeli árfolyamára vonatkozó várakozások el kell mozduljanak az árak hosszú távú trendjétől, ha valamilyen természeti csapás következtében elpusztult a termés fele, és erről a piaci szerep-

11 A sztochasztikus modellek esetében az alkalmazott feltételrendszer nem határozza meg egyértelmüen, hogy egy kérdéses esemény bekövetkezik-e, vagy sem - a determinisztikus modellek esetében persze más a helyzet, ott az eredmény egyértelmü lesz (bekövetkezés vs. nem bekövetkezés). Még inkább egyértelmü a megkülönböztetés, ha arra gondolunk, hogy egy determinisztikus modell egyenlete konkrét számértéket ad eredményül az inputok behelyettesítéseként (a modell paraméterei által befolyásolva); egy sztochasztikus modell outputja ezzel szemben egy valószínűség-eloszlás. A statisztikai és ökonometriai módszereken alapuló becslésekre éppen ez jellemző, hiszen a pontbecslésekmellettmegadhatókolyankonfidencia-intervallumokis, amelyeképpenakérdésespontbecslésvalószínüségeloszlását mutatják meg. John Weeks érveléséböl ugyanakkor az is kiderül, hogy a PFH müködésének cáfolata nem is olyan egyszerü. A gyakori érv az, hogy a tökéletes elörelátáshoz olyan mennyiségű információ összegyüjtésére és feldolgozására volna szükség, amelyre a hasznosságmaximalizálás egyszerüen már nem ad magyarázatot - a PFH eszerint tehát nem lenne gazdaságos, bár persze müködését nem lehetne kizárni. Weeks ehelyett ontológiai alapon igyekszik kritikáját megfogalmazni (Weeks 1998:149), és azt az implicit előfeltevést igyekszik cáfolni, amely szerint a jövő megismerése és előrejelzése kizárólag a feldolgozott információk mennyiségén alapul. Nyilvánvaló, hogy a jövő tökéletes ismerete legfeljebb determinisztikus viszonyok között lehetne elképzelhetö, ahol a véletlen nem kap szerepet. Kenneth Arrow egyébként szemléletes példa keretében mutatja be, hogy ha a véletlen szerephez jut, a jövőbeli folyamatok teljes bizonyossággal nem lesznek elöre jelezhetők, bár kétségtelen, hogy a mind nagyobb mennyiségü információ birtoklása és feldolgozása csökkenti a bizonytalanságot (Arrow 1979:368).

12 A legegyszerübb extrapolatív modell az $x_{t}^{e}=x_{t-1}+\alpha\left(x_{t-1}-x_{t-2}\right)$ formában írható fel, ahol $x_{t}^{e}$ az $x_{t}$ változóra vonatkozó, a $t-1$ idöpontban kialakított várakozás. Észre kell venni, hogy ha $\alpha>0$, akkor $x_{t}^{e}$ az $x_{t-1}$ extrapolációjaként fog alakulni, a változó legutóbbi módosulását figyelembe véve, engedelmeskedve a változás irányának. Ha $\alpha>0$, akkor a legegyszerübb, naiv sémával állunk szemben, vagyis a gazdasági szereplök a jelen egyszerü folytatódására számítanak. A harmadik esetben, ha $\alpha>0$, a változó korábbi szintjét prognosztizáló regresszív séma lép müködésbe. A különféle várakozásképzési operátorokról, használatuk lehetőségeiről kiváló összefoglalást nyújt Visco (1984).

${ }^{13}$ Az adaptív modell lényege, hogy a korábbi (rendszerint a tárgyidőszakot megelőző periódusra kialakított) várakozás alapján kalkulált tévedés (vagyis e várakozás és a megfelelö időszak tényadata közötti eltérés) lép be korrekciós tényezőként a tárgyidőszakra vonatkozó várakozások kialakításánál. Algebrailag kifejezve: $x_{t}^{e}=x_{t-1}^{e}+\beta\left(x_{t-1}-x_{t-1}^{e}\right)$.

14 Talán helyesebb lenne, ha ezt a kitételt a racionális várakozásokról adott különféle definíciók közös elemének tekintenénk. 
lők tudomást is szereznek (vö. Pete 2001:134). Ki kell emelni azonban, hogy adaptivitás és racionalitás szembeállítása nem feltétlenül indokolt, vagyis elképzelhetők olyan szituációk, amelyekben az adaptív séma követése lesz racionális. Az előbbi példához visszatérve: ha sem természeti katasztrófa, sem egyéb olyan tényező nem lépett fel, amely eltéríthetné a kávé árfolyamát annak hosszú távú trendjétől, a piaci szereplők racionálisan, minden információt felhasználva a korábbi folyamatok további müködésére számíthatnak - ebben az esetben tehát az adaptív séma követése mindenben megfelel a Muth által adott (erös) hipotézisnek.

A társadalomelméleti irodalomban - beleértve a gazdaságelméleti területet is - több racionalitásdefiníció forog közszájon. Mi a helyzet tehát a racionális várakozások gyenge hipotézisével? Tömör megfogalmazása szerint ez nem mond ki egyebet, mint hogy valamely (gazdasági) változó jövőbeli értékére vonatkozó előrejelzést a racionális gazdasági szereplők úgy alakítanak ki, hogy a leghatékonyabb módon felhasználják az összes nyilvános információt azon tényezőkre vonatkozóan, amelyek vélekedésük szerint hatást gyakorolnak a kérdéses változó jövőbeli alakulására (Horváth 2000). Jól látható, hogy ez a definíció semmit sem árul el magáról a várakozásról, mindössze képzéséről tudunk meg valamit - ez alapján pedig más lesz a racionálisnak tekinthető előrejelzés, mint az erős hipotézis esetében, ahol a valószínüség-eloszlásra való hivatkozás fontos többletet hordoz. A kávéárfolyamok példájához visszatérve: a költségek és hasznok összevetése alapján optimalizáló piaci szereplő addig a pontig fogja folytatni az információk beszerzését és feldolgozását, amíg ennek költségei meg nem haladják az ezek révén elérhető hasznokat (illetve az elkerülhető veszteségeket). E gyengébb hipotézis szerint egy befektető a kávéültetvényeket érintő időjárási csapások bekövetkezte után is racionálisan számíthat az árfolyam trendet követő viselkedésére, ha a vélekedésének megváltoztatásához szükséges információk beszerzése költségesebb, mint téves várakozásaiból adódó (potenciális) vesztesége. Világos ugyanakkor, hogy ez a kritikus pont minden befektető esetében más és más, hiszen ugyanazon szituációban a befektetés összegétől függően egyes piaci szereplök téves becslés esetén csak csekély összeg elvesztésére számíthatnak, míg mások esetében ez tetemes is lehet. $S$ ha ez így van, szó sem lehet az egyes piaci szereplők várakozásainak konvergenciájáról, hiszen az információfeldolgozási folyamatot különböző ponton felfüggesztve egymástól eltérő becsléseket fognak adni a jövőbeli folyamatokra vonatkozóan (amelyek akár szisztematikus torzítást is tartalmazhatnak). Egy kisbefektető egyszerü trendhosszabbítása tehát racionális lehet a gyenge hipotézis szerint. A racionalitás egyetlen követelménye ebben az esetben mindössze az, hogy a gazdasági szereplő az optimális pont eléréséig folytassa információfeldolgozási tevékenységét, és az ennek megfelelően képzett várakozások racionálisak lesznek.

A birtokolt információk optimális mennyisége csak nehezen interpretálható, amelyhez - ahogy láttuk - szükség lehet a többletinformáció megszerzésével kapcsolatban felmerülő költségeknek, illetve az ezen ismeretek birtoklásából adódó haszonnövekménynek a meghatározására. Az optimalitás egy másik lehetséges megközelítése szerint az információ azon mennyisége nevezhető optimálisnak, amely még érdemben befolyásolja a meghozott döntést. Problémát ekkor csak az jelent, hogy az ekként értelmezett optimalitás legfeljebb ex post ítélhető meg. Ebben az esetben arra az információs egységre már nincs szükség, amely már változatlanul hagyja a korábban kialakított és akkor az újabb és újabb információk hatására (akár) folyamatosan módosuló döntést. Ennek nyilvánvalóvá válásához azonban szükséges, hogy az utóbb szükségtelennek bizonyuló információegységet is meg- 
szerezzük (vagyis ex ante nem tudhatjuk, hogy egy információs egység felesleges lesz). Ez a definíció semmiképp sem lenne kielégítő, hiszen akár tévedhetünk is, ha azt tételezzük fel, hogy az $n+1$-edik egységnyi információ nem fogja már befolyásolni döntésünket, ha e vélekedés alapja mindössze az, hogy az $n$-edik egység megszerzése után nem módosítottuk várakozásunkat - ennek feltételezése egyenértékủ lenne azzal, mintha azt gondolnánk, hogy a releváns információk mindig a sor elején állnak (fontossági sorrendben), valamint ha egy információs egységről megszerzése után kiderül, hogy birtoklása haszontalan (abban az értelemben, hogy hatására nem revideáljuk korábbi álláspontunkat), akkor nyugodt szívvel gondolhatjuk, hogy ezek után már nem is jutnánk érdemi többletismerethez. Az optimum továbbá lehet egyfajta szubjektív optimum is, amikor a becslést készítő úgy gondolja, hogy minden szükséges információt beszerzett és feldolgozott. Ezen dilemmák elkerülése érdekében a racionális döntések szociológiai elmélete például egyszerü időbeli optimalizálásból indul ki, vagyis addig tartja helyesnek az ismeretek gyüjtését, amíg e folyamat nem veszélyezteti a döntés meghozatalát (vö. Elster 2001:33) - ez a szabály azonban nem mond többet ki annál, mint hogy a döntési helyzet elmúltával (azaz, ha már elszalasztottuk azt a pillanatot, amikor döntésünket még meghozhattuk volna) már nem érdemes újabb információk után kutatni.

Észre kell venni, hogy a $R E H$ gyenge hipotézise a vélekedés és annak alapja közti viszonyt vizsgálja (ezt a megállapítást rövidesen tovább árnyaljuk), s emiatt ez a fogalom közeli kapcsolatban áll a szociológiaelméleti irodalomban felmerülő meghatározásokkal. A racionalitás ezek szerint a vélekedés és a vélekedés alapja közötti viszony - amelyet semmiképp sem szabad összetéveszteni az igazsággal, ami viszont a vélekedés és a vélekedés tárgya viszonylatában értelmezhető (vö. Elster 2001:33). E mérsékelt szociológiai fogalom szerint Othelló racionálisan vélekedik, amikor azt hiszi, hogy Desdemona hütlenné válik hozzá, hiszen a rendelkezésre álló információk alapján ez a következtetés tünik logikusnak. Ennél többet pedig a $R E H$ gyenge hipotézise sem állít, vagyis a racionalitásnak nem feltétele, hogy a vélekedések helyesek legyenek, vagyis a gyenge hipotézis szerint a várakozásoknak nem kell egybeesniük sem a későbbi tényleges kimenetekkel, sem azok előzetesen ismert valószínűség-eloszlásának várható értékével.

A REH erős hipotézise ennél azonban messzebbre megy. A racionalitás fogalmához a vélekedés és a vélekedés tárgya közti viszonyt is hozzákapcsolja, sőt, gyakorlatilag kizárólag erre koncentrál; vagyis a helyesség is bekerül a kritériumok közé, s mindezt úgy teheti meg - mivel a vélekedés nem egy jelenbeli, ellenőrizhető tényre irányul -, hogy a pontosság továbbra sem lesz feltétel. Ha a racionális várakozások erős hipotéziséhez hasonlóan rigorózus fogalmat szeretnénk alkalmazni a jelenben ellenőrizhető tények közegében, akkor a vélekedések racionálisnak minősítésével kapcsolatban ez egyet jelentene a vélekedések igazságának megkövetelésével: Othelló gyanúja nem lenne racionálisnak tekinthető, hiszen Desdemona valójában hủ maradt hozzá. Nem szabad ugyanakkor megfeledkezni arról, hogy a $R E H$ jövőbeli folyamatok jelenbeli becsléseit írja le, és ha ebben az idődimenzióban követelnénk meg pontosságot, ez nem lenne más, mint a $P F H$ teljesülésének elvárása (tökéletes előrelátás azonban sztochasztikus viszonyok között elképzelhetetlen). A jelenben a jövőre vonatkozó legtöbb ismeretet a még be nem következett kimenetek valószínűség-eloszlásának ismerete jelenti; a $R E H$ erős hipotézise tehát a jövő lehető legpontosabb ismeretét követeli meg, ami persze nem lehet több, mint annak elvárása, hogy a gazdasági szereplők 
várakozásai kövessék a jövőbeli folyamatok objektív valószínüség-eloszlását. ${ }^{15}$ Csak a társadalmi és gazdasági folyamatok sztochasztikus jellege miatt nem beszélhetünk pontosságról a kritériumok között.

Úgy tünik, a REH erős hipotézise olyan kritériumot szolgáltat, amely alapján szubjektív értékítélet nélkül is besorolhatók az egyes aktorok által képzett vélekedések racionális, illetve nem racionális kategóriába. A gyenge hipotézis alapján egy efféle döntés meghozatala már sokkal problémásabb, hiszen egy, valamely vélekedés racionalitására vonatkozó külső értékelés a tudásra vonatkozó tudást is feltételez, vagyis ismerni kell azt az információs állományt, amelyre támaszkodva a vizsgált szereplö döntését meghozta. ${ }^{16}$ Érdemes azon is elgondolkodni, hogy vajon mi a gyenge hipotézis esetében a racionalitástól való megfosztás itélkezési kritériuma. Mondhatjuk, hogy egy bizonyos előrejelzés nem racionális, ha az azt kialakító piaci szereplő még az optimális pont előtt befejezi az információk gyüjtését; ebben a helyzetben nem is érdemes vizsgálni, hogy mi a viszony a vélekedés és a vélekedés alapja között, hiszen a rendelkezésre álló információk elégtelenek. Az a piaci szereplő, aki óriási összegeket fektetett a kávéüzletbe, bízva annak sikerében, aligha nevezhetö racionálisan várakozó ágensnek, ha a jövőbeli árfolyamok alakulását érintő eseményekről mindössze a tévéhíradóból vagy a szomszédjától igyekszik információkhoz jutni (hacsak a szomszédja nem brazíliai kávéültetvényes); még akkor sem, ha ezen információk által kialakított várakozása összhangban van is a rendelkezésére álló ismeretekkel. A racionalitás elvitatásának alapja ekkor nem az ésszerütlenség (bár kétségtelen, hogy a „racionalitás” hétköznapi értelme ezt diktálná), hanem az, hogy a kérdéses szereplő nem jutott az optimális mennyiségü információ birtokába. Ha a gyenge hipotézis csak a vélekedés alapja és a vélekedés közti viszonyt vizsgálná, az információgyüjtésre fordított csekély erőfeszítés nyomán (gondoljunk csak a kávépiaci kisbefektető iménti példájára) - nem tudva meg semmit az időjárás által okozott károkról - az árfolyamok trendet követő jövőbeli pályáját prognosztizáló piaci szereplő racionálisan várakozna. Ám a gyenge hipotézis szerint van egy másik lehetőség is a racionalitástól való megfosztásra. Ha a vizsgált piaci szereplő az információfeldolgozás során el is jutott az optimális mennyiség birtoklásához (bárhogyan definiáljuk is e mennyiséget), ez alapján még mindig kialakíthat olyan vélekedést, ami ellentmond ismereteinek. Ez a

15 Úgy tünik, a szociológusok előtt nem nyilvánvaló az idődimenzió problémája, és egy jövőre vonatkozó döntés, illetve vélekedés racionalitását is elvitatják, ha utólag tévesnek bizonyul (vö. Farkas 2006). A tanmese egy munkakeresőröl szól, aki elfogad egy állásajánlatot, mert úgy gondolja, hogy az számára - figyelembe véve preferenciarendszerét - a legideálisabb. E döntéséhez a döntés aktusa elött hozzáférhetö valamennyi releváns információt összegyüjti. Utóbb azonban csalatkozik, hiszen például a vártnál kevesebb szabadidővel rendelkezett munkavégzése során, vagy a bérre vonatkozó elképzelései nem teljesültek. Némelyek úgy gondolják, hogy ekkor a döntés (várakozás) racionalitása elvitatható - ök azonban nem veszik észre, hogy a valóság elözetes ismeretét követelik meg úgy, hogy eközben e tudással ők sem rendelkeznek (hiszen a racionalitás elvitatása részükről utólag történik meg).

${ }^{16}$ Ezen a ponton kell említést tenni a muth-i definíció kiegészítő megjegyzése által okozott zavarról. A közös információs készletre vonatkozó kiegészítő kitétel jól észrevehetően hidat ver a REH gyenge hipotézisének irányába, hiszen ha a gazdasági szereplők valamely csoportja a releváns modell inputjainál kevesebb információt birtokol, az így képzett várakozásaik Muth szerint továbbra is racionálisak maradhatnak, habár torzítottak lesznek. Nyugodtan kimondhatjuk tehát, hogy a REH erős és gyenge hipotézise egyaránt Muth definíciójára kanyarodik vissza, csak annak más-más elemeit állítja a tételek középpontjába. Muth (teljes) hipotézisének alkalmazása túlságosan kényelmes (ám zavaros) helyzetbe hozna minket, hiszen ha nem is teljesülnek az erös definíció követelményei, a gyenge hipotézis még továbbra is müködésbe hozható (annak minden kuszaságával együtt). A legnagyobb gondot az jelentené, hogy e teljes hipotézis alapján nem lehet megmondani, hogy mit is kell racionális módon képzett várakozásnak tekinteni. Láttuk, hogy a gyenge és az erős definíció által támasztott követelmények mennyire eltérők, így semmiképp sem pártolható e két definíció összemosása. Nem meglepő tehát, ha az újklasszikusok a későbbiekben kizárólag az erős definícióra összpontosítottak (a továbbiakban a REH alatt mi is annak erős hipotézisét értjük). 
klasszikus példa esete: a kávétermés elpusztulása után az árak változatlan szinten maradását prognosztizáló befektető szintén nem racionálisan várakozik. A $R E H$ gyenge hipotézise tehát két kritériumot állít fel, a köztük való viszonyt azonban tisztázatlanul hagyja. Vegyük észre azt is, hogy analitikai szempontból alig ér valamit, ha a gyenge hipotézis szerint azt állítjuk (vagy legalábbis feltételezzük), hogy a piaci szereplök racionális módon képezik előrejelzéseiket. Egy efféle kijelentés igazsága mellett az előrejelzések akár végtelenül heterogének is lehetnek, s erre a feltevésre aligha lehetett volna az újklasszikus makroökonómia gazdaságpolitikai elemzési apparátusát és következtetéseit felépíteni. ${ }^{17} \mathrm{~A}$ legföbb probléma mégis az, hogy a gyenge hipotézis annyira óvatosan fogalmaz, hogy ennek eredményeként már szinte semmi olyat nem állít, amit a közgazdászok józan eszükre hallgatva már ne tudnának nemzedékek óta (a piaci szereplők döntéseikhez információt gyüjtenek, és vélekedéseiket ezek ismeretében alakítják ki).

Az erős hipotézis ezeket a problémákat megkerüli - bár helyette másokat teremt. A racionalitás feltétele ekkor mindössze az, hogy a piaci szereplök a folyamatok valószínúségeloszlásával konzisztens módon alakítsák ki várakozásaikat. ${ }^{18}$ Egy ilyen definíció birtokában az ítéletalkotás könnyü feladat: racionálisan várakozik az a piaci szereplő, akinek előrejelzése egybeesik a jövőbeli folyamatok várható kimenetelével. Nem merül fel az optimum ködös és nem egyértelmü értelmezésének problémája, és nem kell a tudásra vonatkozó tudással sem rendelkezni - bár, ahogy látni fogjuk, a várakozásképzés homályban hagyott háttere jelenti az erős hipotézis egyik legnagyobb gondját.

\section{Racionális várakozások és a torzítatlanság}

De térjünk vissza e rövid kitérő után a Muth által adott erős definícióhoz! Az ártatlannak tünő megfogalmazások gyanúra adnak okot. Ha a releváns modell által szolgáltatott, illetve a gazdasági szereplők készítette becslések eloszlásfüggvénye (illetve az ebből származtatott sürüségfüggvény) azonos, akkor ebből természetes módon adódik, hogy a gazdasági szereplők által adott becslések torzítatlanok lesznek (hiszen azonos lesz az eloszlás várható érté-

17 Ennek ellenére voltak a szakirodalomban arra vonatkozó kezdeményezések, hogy a gyenge hipotézis implicit elfogadásából az erős hipotézis következtetései kerüljenek levonásra. Ezek azonban semmiképp sem tekinthetők logikailag konzisztens kísérleteknek (vö. pl. Shaw 1984:47-50).

18 A REH erös hipotézise által birtokolt erős mérce hiánya a gyenge hipotézis esetében a szubjektiv ítélet problémáját is felveti. Nyilvánvaló, hogy a racionalitás elvitatása, illetve elismerése külső szemlélő (például egy tudományos megfigyelö) által történik. Ha fel is tételezzük, hogy a külső szemlélö ismeri a megfigyelt piaci szereplö által birtokolt információs állományt, s ha fel is tételezzük, hogy ezen állomány optimális mennyiségü, az ez alapján levont következtetés tekintetében kialakulhat véleménykülönbség a két fél között. A vélekedés és a vélekedés alapja közti viszony képlékeny. Ismét a kávéültetvények példájához fordulva: hiába szerez tudomást a befektető a fagykárokról, és hiába számít ezek után az árfolyamok jövőbeli emelkedésére, vajon milyen mértékű árfolyam-ingadozás prognosztizálása tekinthető racionálisnak? Ha a befektető 25\%-os emelkedésre számít, miközben a megfigyelö 50\%-ot jelez elöre (vagy fordítva), a várakozás racionalitása elvitatásra kerül majd. A gyenge hipotézis tehát azért is támadható (az eddigieken túlmenően), mert tisztázatlanul hagyja a vélekedés alapja és a vélekedés között fennálló kapcsolat természetét (bár eközben egy ítélet tárgyává teszi). Az erős hipotézis ezen a ponton a releváns gazdaságelméletre hivatkozik, amely egy jól meghatározott outputot szolgáltat - a mérce tehát egyértelmü. A gyenge hipotézis azonban egy képlékeny információs kör (akár minden piaci szereplö más információkat birtokolhat), s egy egyértelmü várakozásképzési mód (a releváns gazdaságelméletre és makrogazdasági modellre vonatkozó hivatkozás) hiányában valójában azt állítja, hogy a magatartásra vonatkozó döntéseket - Berlin hasonlatával élve - akár logarléc használatával is meg lehet hozni (Berlin 1990:441). Számos oldalról kritizálható lenne egy olyan magatartás, amelyben a tudományos szerepben tetszelgő megfigyelö saját ítéletét magasabb rendünek tételezné a megfigyelt személy vélekedésénél - és szinte közvetlenek azok a szálak, amelyek a paternalizmusról folytatott vitához kapcsolják e diskurzust (vö. Mill 1980:37-109). 
ke), de még a becslések varianciája (vagyis a várható értéktől való átlagos eltérés) is meg fog egyezni. A racionális várakozások erős értelmezése tehát így azt jelentené, hogy a gazdasági szereplők ugyanazt várják, mint ami a kérdéses makrogazdasági rendszert leíró releváns elmélet outputját jelenti. Tökéletes elörelátássá azért nem merevedhet a mechanizmus, hiszen hibák adódhatnak, vagyis végső soron nem lesz igaz az, hogy a gazdasági szereplők várakozásai egytől egyig azonosak lesznek (és lássuk be, a tökéletes előrelátás - ami definíciószerüen zárja ki a tévedés lehetőségét - egyben a várakozások azonosságát is jelentené). Azt, hogy Muth valóban az elmélet és a gazdasági szereplők várakozásainak azonos eloszlására gondolt, az is bizonyítja, hogy kizárja annak lehetőségét, hogy az elmélet felhasználásával jobb becsléseket lehetne készíteni (Muth 1961:318). Alapvető tehát a különbség a kizárólag a múltbeli információkra támaszkodó adaptív (és az említett egyéb) modell, valamint a racionálisan működő mechanizmus végkimenete között, hiszen előbbiek esetében nyilvánvalóan szisztematikus torzítás léphet fel a tényleges folyamatokhoz (illetve a releváns modell által készített becslésekhez) képest - racionalitás mellett ez a torzítás (elviekben) kizárt. Látni fogjuk azonban, hogy éppen a torzítatlanság jelenti a $R E H$ leginkább vitatható elemét, amelynek feltételezése valójában csak komoly fenntartások megfogalmazása mellett tartható fenn. Semmiképp sem fogadható el az a nagyvonalú értékelés, amely szerint a rendszer mögött valójában csak az információk hatékony kihasználására való törekvés áll, és hogy az információkezelési és -szerzési folyamat egyetlen magyarázó változója a profitmaximalizálás ${ }^{19}$ (vö. Kantor 1979) - ez legfeljebb a motívumokra adhat magyarázatot. Kétségtelen, hogy a $R E H$ az információk hasznosításának jelentőségére hívja fel a figyelmet (vö. Black 2002:389), annak módszere azonban mindvégig homályban marad.

Az előző bekezdésben elmondottakkal kapcsolatban néhány kiegészítő megjegyzést kell tenni. Bár Muth látszólag kizárta annak lehetőségét, hogy az elmélet felhasználásával jobb (sic!) várakozások képezhetők, mint a cégek becslései a várakozások racionalitása mellett, egy helyen azt is megjegyzi, hogy az egyes cégek által készített elörejelzések nagyobb hibákat véthetnek, mint az elmélet ${ }^{20}$ (Muth 1961:317). Kétségtelenül óvatos a megfogalmazás, ahogy az is, hogy Muth nem mondja ki határozottan, hogy a már említett szubjektív és objektív valószínüség-eloszlások azonosak, mindössze annyit állít, hogy a két eloszlás hajlamos arra, hogy azonos legyen. ${ }^{21} \mathrm{~A}$ látszólagos ellentmondás persze feloldásra kerül, hiszen Muth közli, hogy racionális várakozások esetén a piaci szereplők aggregált (és nem egyedi) várakozásai fognak egybeesni az elmélet által nyújtott becsléssel (és így várhatóan a tényleges kimenetekkel). Bár igaz az is, hogy a véletlen hibák térítik el a piaci szereplők egyedi jövendöléseit a későbbi tényadatoktól, és hogy a hibák várható értéke zérus (biztosítandó azt, hogy az aggregált egyedi becslések egybeessenek a modell jövendöléseivel), kiegészítve mindezt a később tárgyalandó ortogonalitás kritériumával, a hibák abszolút értékének alakulása mögött a Muth által elmondottak alapján valamiféle divergencia mutatkozik egyéb,

19 Ezzel összefüggésben meg kell említeni, hogy a REH azért válthatta fel sikerrel a korábbi adaptív sémát, mert a várakozások adaptív képzése aligha volt összeegyeztethető a hasznosságérzet maximalizálására való törekvés hagyományos feltételezésével (vö. Shaw 1984:42).

20 Ami implicite azt jelenti, hogy a releváns elmélet által nyújtott elörejelzések sem pontosak, vagyis a PFH követelményeit sem a releváns modell, sem az aggregált elörejelzések nem teljesítik. A REH egyes definíciói ennél merészebben fogalmaznak azt állítva, hogy az aktorok várakozásai aggregált szinten pontosak (Begg 1982:29).

${ }^{21}$ "[....] expectations of firms (or, more generally, the subjective probability distribution of outcomes) tend to be distributed, for the same information set, about the prediction of the theory (or the »objective "probability distribution of outcomes)" (Muth 1961:316) (kiemelések: G. P.). Kérdés persze, hogy mi történik akkor, ha a felhasznált információs készlet jelentős mértékben eltér, és hogy vajon a torzítatlanság ilyen körülmények között is fenntartható marad-e. 
homályban hagyott változók befolyása alatt. Nem mindegy tehát - még látszólag sem -, hogy ki készíti a becsléseket. Az aggregált torzitatlanság a feltételezés szintjén még így is adott, a szisztematikus tévedés lehetősége tehát ki lett zárva. ${ }^{22}$ Ahogy a releváns modell torzítatlan becsléseket képes szolgáltatni, ugyanúgy torzítatlanok lesznek összességükben az egyedi elörejelzések is. Egészen nyilvánvaló azonban, hogy a releváns modellt aligha ismeri bárki is (legalábbis nem teljes egészében), hiszen Muth szerint a várakozások jelentős keresztmetszeti eltéréseket mutatnak (megfogalmazásában kerülve a feltételes mód használatát), amiből egyébként az egyedi becslések torzítottságára is lehetne következtetni, hiszen - ahogy látni fogjuk - a hiányos információkon alapuló becslések nagy valószínűséggel torzításhoz vezetnek. ${ }^{23}$ Azt, hogy a becslések készítésénél végső soron a modell ténylegesen nem kerül használatra, az is mutatja, ahogy Muth a keletkezett várakozások pontosságával kapcsolatban megjegyzi, hogy azok átlagukat tekintve, vagyis aggregált szinten, ugyanolyan pontosak (sic!), mint a bonyolult egyenletrendszerek outputjai - amiböl az következik, hogy e becslések valamely egyéb módon készülnek - sőt, Muth arra is felhívja a figyelmet, hogy elmélete nem állítja azt, hogy a gazdasági szereplők becslésekkel kapcsolatos tevékenységei hasonlítanának az egyenletrendszereket alkalmazó módszerekre (Muth 1961:317), bár azt igen, hogy a várakozások formálódásának módja a gazdasági rendszert leíró releváns elmélettől függ (Muth 1961:316). A kétféle várakozás (vagyis a piaci szereplőké és a releváns gazdaságelméleté) tehát nem azonos, csak egyforma. Mindez súlyos következményekkel jár, hiszen így most már nem csak azt kell megmondani, hogy miként épül fel a modell (és hogy miként lehet az erre vonatkozó tudást elsajátítani), hanem azt is meg kell magyarázni, hogy a piaci szereplők miként jutnak egy olyan tudás birtokába, ami valójában nem azonos a releváns modell ismeretével, csak teljesen hasonló hozzá (legalábbis eredményeiben ${ }^{24}$ ).

Valójában egyszerübb volna a helyzet, ha feltételezhetnénk, hogy a gazdasági szereplök az ökonometriában és a gazdaságelméletben jártas ágensek. Ekkor, ha igaz, hogy e szereplők és a releváns gazdaságelmélet egyenként azonos értékü (s csak a véletlen hatását tükröző eltéréseket tartalmazó) információs készlet felett rendelkeznek (beleértve a modell specifikálására vonatkozó ismereteket is), az egyedi becslések kivétel nélkül a folyamatok torzítatlan becsléseit fogják szolgáltatni, továbbá a paraméterbecslések valószínűségeloszlásának centrumában ott fog állni a releváns modell; az elméleti paraméterek azonban nem ismertek - legfeljebb csak az alkalmazott függvényformák. (Ennyiben tehát megvalósulhatna a releváns modell aktorok általi ismerete és kiaknázása, még ha az inputokkal való feltöltés feladata az egyedi szereplökre marad is). Teljesülne tehát Muth azon követelménye,

22 A torzítatlanság követelménye sztochasztikus viszonyok között azt jelenti, hogy a paraméterbecslések várható értéke a becsült elméleti paraméter, és a becsléseket véletlenszerü hibák térítik el attól, hogy az egyes becslések esetében teljesüljön az elméleti és az empirikus paraméterek egyezése.

${ }^{23}$ Az OLS-becslések minden esetben biztosítják, hogy a hibák várható értéke zérus legyen - ebből azonban nem lehet következtetni a modell, valamint a modellel készített becslések torzítatlanságára. Mindemellett az is igaz, hogy minél kevesebb információ kerül kiaknázásra a modell specifikálása során (vagyis minél több releváns változót rekesztenek ki), az eltérésnégyzet-összeg annál nagyobb lesz. Kihagyott releváns változók mellett torzítatlan becslés aligha képzelhetö el.

24 Muth akkor is talányosan fogalmaz, amikor kijelenti: "a várakozások átlagai egy rendszerben pontosabbak a naiv modelleknél, és épp olyan pontosak, mint a bonyolult egyenletrendszerek" [...] (Muth 1961:316). Ismét azzal szembesülünk tehát, hogy a gazdasági szereplök becslései nem matematikai alapokon készülnek (legalábbis nem komplex módszerek felhasználásával). Éppen ez az az érvelési blöff, amelyet Benjamin Friedman és John Weeks is az újklasszikusok szemére hány (és amelyhez nagyon hasonlít az eloszlásfüggvények közeledésére vonatkozó imént említett homályos megfogalmazás is): a várakozások úgy képződnek, mintha a gazdasági szereplök ismernék a releváns modellt (B. Friedman 1979:23; Weeks 1998:152). 
amely szerint a várakozások átlagukat tekintve helyesek (torzítatlanok). Ez a magyarázat azonban nem konzisztens Muth fogalmaival, hiszen az aktorok módszere szerinte nem az ökonometriai modellezésen alapul. Ez a felfogás megmagyarázná a szereplők által elkövetett nagyobb elörejelzési hibákat, az egyedi becslések szintjén azonban várhatóan torzítottságot eredményezne a várakozások képzési folyamatainak kezdetlegessége miatt; ám érthetővé válna, hogy a hibák keresztmetszeti eltéréseket mutatnak az egyes csoportok között (hiszen az előbbiekből az is következik, hogy a magasabb szintű tudást birtoklók jobb becslések készítésére képesek). Ekkor azonban semmiféle értelmes magyarázat nem adható arra, hogy az egyébként torzított egyedi becslések átlaga mitől szolgáltatná a tényleges folyamatok torzítatlan becsléseit.

A két magyarázati lehetőség (az aktorok jól informált professzionális modellezők vs. az aktorok várakozásai kezdetlegesek) más-más módon konzisztensek Muth definíciójával. Az első lehetőség következményeit tekintve: az egyedi becslések torzítatlanok; a második pedig feltételezéseit illetően: a gazdasági szereplők módszere nem bonyolult ökonometriai alapokon áll. Úgy tünik, a Muth által adott definíció e két kitétele együttesen csak nagy nehézségek árán tartható fenn. Az a lehetőség pedig kizárható, hogy Muth a releváns modell outputjainak gazdasági szereplők általi alkalmazására gondolt volna, hiszen ha így lenne, nem beszélhetnénk a várakozások tekintetében keresztmetszeti különbségekről. S így valójában a mintha-érvelés is elgyengül, hiszen ha igaz lenne, hogy az aktorok várakozásai úgy képződnek, mint a releváns modell outputjai, akkor teljesen tisztázatlan marad, honnan származnak a Muth által említett keresztmetszeti véleménykülönbségek.

Azt mondhatjuk, hogy a racionális várakozások elméletét alkalmazva az újklaszszikus csoport ezen a ponton a bizonyítandóval bizonyít. A torzítatlanság azért fontos kritérium, mert a szisztematikus anticiklikus monetáris politika hatásosságának lehetőségét az újklasszikus elmélet követői erre hivatkozva tagadják - ha tehát nincs torzítás, nincs monetáris oldalról érkező stimulálási lehetőség. S az újklasszikusok szerint ez fordítva is igaz: ha az output szabályozása a monetáris politika segítségével nem valósítható meg, ebből a becslések torzítatlanságára lehet következtetni (illetve kell következtetni, hiszen a racionális várakozások elmélete per definitionem kötette ki a torzítatlanságot). ${ }^{25}$ Legfontosabb kérdésünk tehát annak megvizsgálása, hogy a várakozások torzítatlansága erősen leegyszerűsítő, avagy hihető (tartható) előfeltevés a $R E H$ részéről, hiszen ha sikerülne belátni, hogy e feltételezés fenntartása reálisan nem képzelhető el, ez a fejlemény jelentősen csorbítaná a $R E H$ relevan-

25 Ezen a ponton érdemes szót ejteni Weeks érveléséröl (Weeks 1998:151), amely szerint a REH abban is bünös, hogy a valóságot determinisztikus törvényeknek engedelmeskedőként szemléli. Ennek belátása mindenképpen problémás. A helyzetünk könnyebb volna, ha elfogadhatnánk azt az első látásra kényelmes feltételezést, hogy a gazdasági szereplők és a releváns modell becslései azonosak (a fenti értelemben). Ha létezik a gazdaság müködésére vonatkozó teljes tudás (mint ahogy a REH állítja), modellbecslések segítségével a jövő determinisztikus módon bekövetkezö eseményei pontosan (és nem csak torzítatlanul) elöre jelezhetök volnának - ekkor viszont a REH és a PFH ekvivalens volna az egyes aktorok szintjén is - ezt viszont a REH nem állítja. Emiatt tehát - legalábbis ami az explicit feltételezéseket illeti - nem lehet szó determinizmusról. A determinizmus vádja úgy tünik, hogy ezen a szinten egészen prózai ok miatt hamis, hiszen Muth megfogalmazásából kiderül, hogy maga az elmélet sem képes pontos, csak torzítatlan elörejelzésre (Muth 1961:317-318). Más kérés azonban, hogy például a munkapiac müködéséhez - ahogy azt az újklasszikusok elképzelik - aPFH müködésére igenis szükség van. 
ciáját, valamint az újklasszikusok gazdaságpolitikai következtetéseinek helytállóságát is. $^{26}$

Nem mellékes körülmény, és erre itt kell felhívni a figyelmet, hogy a $R E H$ elemzése során kétféle várakozásról, kétféle becslésről kell szót ejteni - a későbbiek során ehhez fogunk ragaszkodni -, hiszen meg kell különböztetni a releváns modellel készített becsléseket, illetve a gazdasági szereplők elörejelzéseit. Észre lehet venni ugyanakkor, hogy a releváns modellre valójában nincs is szükség, hacsak azért nem, hogy vezesse az aktorok mintha-várakozásait. A monetáris politika megtévesztési szándéka az aktorokra irányul, az ő várakozásaik torzítatlansága lényeges - eközben a releváns modell torzítatlansága (ha van ilyen egyáltalán) gyakorlatilag lényegtelen momentum. Szükséges tehát áttekinteni, minek kell ahhoz teljesülni, hogy a gazdasági szereplők, illetve maga a releváns modell torzítatlan becsléseket adhasson - úgy fogunk eljárni, hogy a gazdaság szereplöit professzionális ökonometriai modellezőknek tekintjük, hiszen másként torzítatlan egyedi becsléseket csak bajosan lehetne feltételezni. Ha arra jutunk, hogy bizonyos körülmények között a gazdasági szereplők képesek torzítatlan becslések előállítására, akkor a kritikát más területre, vagyis a körülményekre kell összpontosítani, kifogásolva például, hogy a sarki közértesröl aligha lehet magasabb szintű matematikai tudást felételezni. A releváns modell létezése, illetve sikeres specifikálásának lehetősége, valamint a gazdasági szereplők becsléseinek torzítatlansága tehát nem feltételezik egymást, és a gazdaságpolitikai következmények szempontjából kizárólag utóbbiak bírnak relevanciával. Ha a tudásra és információkra vonatkozó szükséges feltételek nem állnak fenn, és így az aktoroktól nem várható torzítatlan becslések készítése, akkor e torzítatlanság csakis a $R E H$ sajátos mintha-feltevése révén biztosítható (ami nyilvánvalóan igazolásra szorulna).

\section{A REH ortogonalitási feltevése}

Az előzőek során megvizsgáltuk, hogy milyen koncepcionális nehézségek adódnak abból, hogy a $R E H$ a gazdasági szereplők által képzett várakozások torzítatlanságából indul ki. Jól láthatóan körbe-körbe kell járnunk, ha az elmélet érvelését kívánjuk követni: nem komplex módszerek alapján az egyedi szereplők aligha juthatnak torzítatlan becslésekhez - ezek

26 Itt azt állítjuk, hogy a REH relevanciája szempontjából meghatározó az általa alkalmazott előfeltevések realitása. Ha el is fogadjuk, hogy a monetarista elmélet nem tüzte ki célul a világ szabatos leírását, az elmélet kritikája ellene fordíthatja ezt a fegyvert - felvállalva persze, hogy ekként olyan témában nyitunk vitát az elmélet képviselöivel, amelyben ők nem fogalmazták meg azt az állítást, amelyet vitatni igyekszünk; eszerint egy elmélet megítélése szempontjából egyedül az számít, hogy az miként képes elöre jelezni valamely jelenséget (vö. pl. M. Friedman 1986:17-50). Máshol Milton Friedman mégis azt hangoztatta, hogy a puszta empirikus összefüggések nem elegendök egy kapcsolat feltételezésére; csak az, ha az elméleti alapvonalak megfelelöen tisztázottak (M. Friedman 1970:229), sőt, Weeks is felhívja a figyelmet, hogy a REH a gazdasági szereplők tényleges viselkedését írja le (Weeks 1998:150). Ám az itt elmondottakkal kapcsolatban természettudományos analógiaként eszünkbe juthat a naprendszer müködését leíró geocentrikus és heliocentrikus modell esete is, amelyek mindegyike alkalmas volt arra, hogy a Nap megfigyelt pályáját leírja, illetve elöre jelezze (vö. Weeks 1998:134) - vagyis egy modell helyessége szempontjából mit sem számít, ha pusztán helyes becslések készítésére alkalmas. A világ valós müködéséről ekkor nem tudunk meg semmit, s így azt sem leszünk képesek megmagyarázni, hogy minek köszönhetően változik az elörejelzések pontossága, ha ez bekövetkezik. Amíg a modell megfelelöen müködik, az outputok konzisztensek lesznek ugyan a valósággal, de nem azért, amivel a modell magyarázza. Mi, a kritikusok, nem elégedhetünk meg azzal, hogy egy modell pontos elörejelzéseket szolgáltat, hiszen ez egyenlö lenne a tudomány fejlödésének megállításával - s ha az alapot pusztán a predikciók helyessége jelenti, a geocentrikus modell meghaladására nem is lett volna szükség. Erre a szempontra elsőként Vígh László hívta fel a figyelmemet. 
eléréséhez professzionális modellezői ismeretekre lenne szükség az aktorok részéről, ezt a körülményt azonban Muth eleve kizárta, és a modellezői módszerekre vonatkozó kikötésekből csakis torzított becslések következhetnek. Torzítatlanságról beszélni tehát a szó legszorosabb értelmében csak előfeltételezésként lehet.

A racionális várakozások elmélete a torzítatlanság mellett azonban az ortogonalitás teljesülését is feltételezi. Előbbi egyszerủen azt jelenti, hogy a tényadat (mint valószínűségi változó) és annak becslése közötti eltérésként definiált hibatag várható értéke zérus. $\mathrm{Az}$ ortogonalitás ezzel szemben azt jelenti, hogy a várakozási hiba nem korrelál a rendelkezésre álló információkészlettel - az ortogonalitás értelmében tehát az ex post (vagyis már a tények ismeretében kalkulált) várakozási hiba nem jelezhető előre ex ante a várakozások kialakításakor rendelkezésre álló és használt információk alapján (Gerrard 1994). Jobban meggondolva mindez szükségszerüen van így, hiszen ha előzetesen meg lehetne becsülni az előrejelzési hibát, maga a várható hiba is a rendelkezésre álló információs készlet elemévé válna (ex ante), amely módosíthatná az éppen kialakítás alatt lévő várakozásokat, s így végső soron hibával nem is kellene számolni, vagyis reductio ad absurdum a $P F H$ általános teljesülésének igen csak erős feltételezéséhez jutnánk (nem lépnénk az utcára, ha tudnánk, hogy a fejünkre fog pottyanni egy cserép). A várakozások racionalitása tehát a $R E H$ szerint mindössze a szisztematikus hibák kizárását jelenti, véletlenszerủ ('́gy elöre nem jelezhető) eltérések (a $R E H$ szerint véletlenszerü ${ }^{27}$ eltérések) - ahogy már utaltunk rá - adódhatnak. Az ortogonalitás követelménye valahogy így lenne felírható a szokásos formulákkal:

$$
\operatorname{cov}\left(e_{t} ; \Omega_{t-1}\right)=0
$$

ahol $e_{t}$ a t-edik időszakban tapasztalt (és a fenti módon definiált) hibatag, $\Omega_{t-1}$ pedig az az információs készlet, amelynek kiaknázásával a $t$-edik időszakra vonatkozó becsléseket készítették a t-1-dik időszak során. Az ortogonalitás azonban egy nagyon fontos következtetéshez vezet. Ha ugyanis abból indulunk ki (és aligha cselekedhetnénk másként), hogy

$$
e_{t-i} \subset \Omega_{t-1} \text {, ahol } i=1,2,3, \ldots
$$

amellyel nem állítunk mást, mint hogy a t-1-dik, valamint az azt megelőző időszakokban megfigyelt előrejelzési hiba az előrejelzés készítése szempontjából meghatározó időszakra vonatkozó információs készlet részét jelenti, tehát a $t$-edik időszakra vonatkozó becslések elkészítésekor a gazdasági szereplők már pontosan ismerték az előző időszakok előrejelzési hibáit. Az ortogonalitásból azonban az is következik, hogy

$$
\operatorname{cov}\left(e_{t} ; e_{t-i}\right)=0, \text { ahol } i=1,2,3, \ldots,
$$

mivel valamennyi korábbi előrejelzési hiba beépült már a rendelkezésre álló információs készletbe (a fenti egyenlőség másként fogalmazva a reziduális autokorreláció hiányának

27 E kitétellel azt igyekszünk hangsúlyozni, hogy a szisztematikus hibák (vagyis a torzítás) kizárása sokkal inkább kijelentés a REH részéről, mintsem korrekt módon védhető, érvekkel alátámasztott megállapítás. 
követelményét jelenti). Vagyis a modell müködéséböl a tanulási folyamat teljes kizárásra kerül, hiszen a gazdasági szereplők a korábbi tévedéseik alapján nem lesznek képesek korrigálni hibáikat, nem tudják megbecsülni, hogy a jelenlegi modellt alkalmazva hogyan fog alakulni a következő időszak elörejelzési hibája. A tanulási folyamat lehetőségének hiányát azonban az okozza, hogy a releváns modell birtokában már csak véletlenszerü (így elöre jelezhetetlen) hibák adódhatnak - vagyis az e hibákból való tanulás szükségtelen, és egyben lehetetlen is. ${ }^{28}$

\section{A torzítatlanság további vizsgálata}

Az előző bekezdésekben elmondottak kivétel nélkül azon a feltételezésen alapultak, hogy a gazdaságra vonatkozó olyan tudás a priori fennáll, amely a tényleges jövőbeli folyamatok torzítatlan becslését képes nyújtani - a releváns modell tehát rendelkezésre áll. Ebben a helyzetben a gazdaság szereplöi például úgy juthatnának e tudás birtokába, hogy egyszerüen közlik azt velük - és másik helyes implicit feltételezés nem képzelhető el, hiszen a hiányos információk miatt a gazdasági szereplők egyedi becslései nagy valószínűséggel torzítottak lesznek. ${ }^{29}$ Most elöször jutunk el valami olyasmihez, ami némiképp emlékeztet az inflációs célkövetési rendszerre, hiszen ebben a helyzetben a gazdasági szereplők hasznosítani tudják a kvázi-releváns gazdasági modell (vagyis a releváns modell legjobb ismert közelítésének) eredményeit (persze jókora passzivitás mellett, hiszen ténylegesen inkább annak outputjait birtokolják, mintsem a modellt alkalmaznák ténylegesen becslések készítésére), és a becslések egybe fognak esni a modell által adott előrejelzésekkel. Ez persze csak látszólag könnyíti meg a dolgunkat, hiszen figyelembe véve a trial and error módszerü specifikáció eleve adott korlátait az elméleti paraméterek meghatározása terén legfeljebb azt mondhatjuk, hogy a teljes tudás létezik, de azt megszerezni, ahhoz eljutni nem lehet - a releváns modellre vonatkozó tudás tehát kényelmes és nélkülözhetetlen előfeltevés, és nem reális következmény.

Más lesz tehát a helyzet, ha abból indulunk ki, hogy a releváns modell a priori egyszerüen nem létezik (csak létezhet), vagyis a gazdasági szereplőknek (és így magának a monetáris hatóságnak is) meg kell keresniük azt. E kérdés nem kerülhető meg, hiszen ha létezhet is releváns modell, valahogy el is kell ahhoz jutni. A REH talán legszellemesebb kritikáját ezeken az alapokon John Weeks fejtette ki. Érvelése figyelemreméltó, hiszen eszerint a releváns modell még akkor sem határozható meg a trial and error módszer alapján, ha elvben a gazdasági rendszerre vonatkozó teljes és tökéletes tudás elképzelhető is. Egy adott gazdasági változó sztochasztikus adatgeneráló folyamata az alábbi módon írható fel:

${ }^{28}$ Érdekes, hogy Thomas Sargent és Neil Wallace egészen hasonló alapokon állva tagadják a szisztematikus gazdaságpolitika lehetöségét (ami egy árnyalattal több annál, mint ha a sikertelenségét állitanák, hiszen az ő érvelésükben már maga a törekvés is lehetetlen). Az aggregált kibocsátás fokozása csakis úgy történhet, ha a monetáris hatóság nem várt árszínvonal-elmozdulásokat gerjeszt. Ahhoz, hogy a meglepetés a t-edik idöszakban sikerüljön, teljesülnie kell annak, hogy a pénzkínálat szisztematikus (vagyis elöre jelezhetö) részen felüli komponense megjósolhatatlan legyen a t-edik időszakra vonatkozó várakozások alapjául szolgáló (és a t-1-edik időszakban rendelkezésre álló) információk alapján. Ám amíg a gazdasági egyéb szereplói és a monetáris hatóság azonos információs halmazzal rendelkezik, a jegybank módszeresen maga is képtelen lesz a véletlenszerü (és a meglepetésért felelös) komponens meghatározására, hiszen az ő esetében is teljesül a rendelkezésére álló információk és a szisztematikus részen felüli pénzkínálati komponens korrelálatlansága (Sargent - Wallace 1975).

${ }^{29}$ Ne feledjük: a gazdasági szereplökröl azt feltételezzük, hogy professzionális gazdasági modellezők! 


$$
y_{t}=x_{t}^{\prime} \beta+u_{t},
$$

ahol $x_{t}$ az $y_{t}$ időbeli alakulását meghatározó valamennyi magyarázó változó vektora (amely így tartalmazza az összes releváns információt), $y_{t}$ a gazdasági változó $t$ időszaki értéke, $\beta$ pedig az elméleti paramétervektor. Ha létezik a gazdasági rendszerre vonatkozó tökéletes tudás, akkor a releváns modell nyilván az elméleti paraméterek ismeretét jelenti, a modellbecslés felírása tehát az alábbi módon történhet meg:

$$
E_{t-1}\left(y_{t}\right)=x_{t}^{\prime} \beta
$$

ahol $E_{t-1}($.$) a kiválasztott változóra adott becslés. A releváns modell becslési hibája ezek$ alapján úgy definiálható, ha a két egyenletet kivonjuk egymásból az alábbi módon:

$$
y_{t}-E_{t-1}\left(y_{t}\right)=u_{t}
$$

A modellbecslést eszerint véletlen hibák térítik el a tényleges kimenetektől, így biztosítva azt, hogy még a releváns modell se legyen képes pontos elörejelzésekre. A torzítatlan egyedi becslések ezek alapján pedig az alábbi formát veszik fel:

$$
E_{t-1}^{i}\left(y_{t}\right)=x_{t}^{\prime} b_{t-1}
$$

ahol $b_{t-1}$ a $t-1$ időszaki becslés készítéséhez felhasznált empirikus paramétervektor. A torzítatlanság követelménye itt azt jelenti, hogy $E\left(b_{t-1}\right)=\beta$. Ha ez teljesül, vagyis, ha a gazdasági szereplők a tényleges folyamatok torzítatlan becsléseit képesek előállítani, akkor a becslési hiba

$$
y_{t}-E_{t-1}^{i}\left(y_{t}\right)=\hat{u_{t}^{i}}
$$

lesz, mivel $E\left(x_{t}^{\prime}\left[\beta-b_{t-1}\right]\right)=0$. Észre kell venni, hogy a releváns modell, illetve az egyedi becslések hibái nem azonosak. Bár a véletlen hatása az egyes egyedi becsléseket eltérítheti az elméleti paramétervektortól, ezek az eltérések aggregált szinten kiegyenlítődnek, és így a paraméterbecslés eloszlásának várható értéke az elméleti paraméter lesz. A becslési hiba azonban nemcsak a specifikációs hibák következménye, hanem a véletlen hatások eredője is lehet - az, hogy éppen minek a következménye, viszont nem deríthető ki. ${ }^{30}$ Éppen ez aka-

30 Ezen a ponton érdemes felhívni a figyelmet, hogy a torzítatlanság, illetve az, hogy a becslési hiba várható értéke zérus, nem szinonim fogalmak. Ahogy korábban említettük, az OLS-becslések minden esetben biztosítják, hogy a hibatag várható értéke zérus legyen. Ezen túlmenően pedig az is igaz, hogy torzított paramétervektor esetén is elöállhat az a helyzet, hogy a becslési hiba várható értéke zérus, ha az elméleti és az empirikus paramétervektorok különbségeként képzett vektor merőleges a magyarázóváltozók vektorára. Más kérdés azonban, hogy ekkor a becslési hiba nem lesz független a magyarázó változóktól, amely csakis az empirikus paramétervektor torzítatlansága mellett lenne kiküszöbölhetö. 
dályozza meg azt, hogy a releváns modellhez empirikus módon eljuthassunk. A modell valamely közbülső (tehát még nem tökéletes, végső) állapotában is szolgáltathat pontos becslést, pusztán a véletlen hatásának engedelmeskedve. Ebben a helyzetben a modell készítője természetesen azt gondolhatja, hogy munkája ezen a ponton véget ért, hiszen valamiféle végső tudás birtokába került. Ennél sokkal érdekesebb az a helyzet, amikor a modell outputja elvéti a későbbi tényadatokat (hiszen ne feledjük, előrejelzések készítéséről van szó). Ez nagyjából két ok miatt következhet be. Egy köztes állapotú modellnél (amelynél jobbat Weeks szerint egyébként el sem lehet képzelni) a modellező egyetlen esetben sem fogja tudni azonosítani, hogy a téves becslés melyik része köszönhető a téves specifikációnak (vagyis mi a szisztematikus rész), s melyik tükrözi a véletlen hatását. Ennek híján képtelen lesz a modellen érdemben javítani. Feltéve, de meg nem engedve, hogy tökéletes modell létezik (bár ennek sikeres specifikálásának folyamatáról a fentiek értelmében aligha lehet számot adni), a folyamatok sztochasztikus jellege miatt hibák ekkor is adódhatnak (hiszen a becslésekkel kapcsolatban a $R E H$ muth-i értelmében szó sincs pontosságról), és ezt tapasztalva a modellező nyilvánvalóan nekiállna a modell újraspecifikálásának - ami egyértelműen visszalépés lenne a megelőző állapothoz képest. Weeks az ökonometria-elméleti apparátus mellőzése mellett találóan jegyzi meg, hogy a modell fokozatos javítása kizárólag úgy lenne elképzelhető, ha előzetesen már ismernénk a modellt, amelyhez lépésről lépésre közelíteni szándékozunk (Weeks 1998:153). A tanulási folyamat eleve elrendelt lehetetlensége, illetve a releváns modell gazdasági szereplők általi ismeretének hiánya együttesen megnehezíti a becslések torzítatlanságának feltételezését. A releváns modell ismerete a szó legszorosabb értelmében vett magasabb rendü tudás, deus ex machina, és mintha a releváns modell képében a walrasi mindentudó árverező kelne újra életre. ${ }^{31}$ Bárki kifogásolhatja persze, hogy miért várjuk el a releváns modelltől az elméleti paraméterek ismeretét. Úgy gondoljuk, ez szükségszerüen következik Muth megfogalmazásából, amely szerint a várakozások átlaga ugyanolyan pontos, mint az egyenletrendszerekkel készített becslés ${ }^{32}$ (persze az érvelésben, ahogy ezt korábban jeleztük, most megfeledkezünk arról, hogy Muth szerint az aktorok ténylegesen nem foglalkoznak modellépítéssel). Hiszen ha professzionális modellezőknek tételezzük fel az aktorokat, akkor a torzítatlan egyedi becslések valószínűség-eloszlásának centrumában az elméleti paraméterek fognak állni, amelyek értéke azonban senki számára nem ismert.

31 Az újklasszikus és az azt megelőző klasszikus elmélet között is számos párhuzam mutatható ki, amelyek közül Filippo Cesarano számos elemet kiemel a pénzmennyiség várt és nem várt növekedésének hatásaira koncentrálva (Cesarano 1983). Jellemzö, hogy a klasszikus közgazdászok is a pénzállomány nem anticipált bővülésének szenteltek nagyobb figyelmet, miközben az elöre látható változásokat gyakorlatilag hatástalannak tételezték (bár az is igaz, hogy kimutatások, illetve információáramlási csatornák híján szinte valamennyi változás váratlannak volt tekinthető - kivéve a bejelentett leértékeléseket). Alapvető törvényszerűségként feltételezték, hogy a pénzmennyiség bővülése csak fokozatosan váltja ki az árszínvonal megfelelő alkalmazkodását, ez elött a reáljövedelem és a foglalkoztatás azonban módosul (vö. Hume 1994:47-48). A hatások kiváltásában a föszerepet nem az árak és a bérek ragadóssága, hanem az információhiány játszotta (ez erősen emlékeztet a REH teoretikusainak álláspontjára, nem mindegy azonban, hogy mire vonatkozóan hiányosak az információk: ezzel összefüggésben a klasszikusok a pénzállományban bekövetkezö változásokra, a REH követői viszont a relatív és az abszolút ármozgások megkülönböztethetőségére koncentrálnak). Cesarano egyébként még azt a megállapítást is megkockáztatja, hogy a klasszikus közgazdászok a gazdasági szereplök részéről implicite feltételezték a gazdasági rendszert leíró releváns modell ismeretét, hiszen - érvelése szerint - azok csak ennek tudatában lehettek képesek felmérni a bejelentett döntések hatásait.

32 "Averages of expectations in an industry are [...] as accurate as elaborate equation systems [...]" (kiemelések: G. P.) (Muth 1961:316). A „pontosság” említése persze némi zavart kelthet, amelyet azonban a korábban elmondottak alapján megfelelően kezelhetünk (és jelen esetben a torzítatlanság szinonimájaként kell értelmeznünk). 
Ha nem hiszünk a gazdaságra vonatkozó teljes és tökéletes tudás létében, akkor legfeljebb azt mondhatjuk, hogy e tökéletes tudás híján minden ökonometriai modell a valóságnak (a tényleges adatgenerálási folyamatnak) csak többé-kevésbé jó közelítése lehet. Természetes, hogy a gazdaság szereplői nem lesznek azonos helyzetben az e tudásért folytatott küzdelmekben - vagyis az egyes aktorok más és más eséllyel állhatnak neki e tevékenységnek, ahol a jobb esélyekkel rendelkezők lehetőséget kapnak arra, hogy a hipotetikus releváns (és ténylegesen nem is létező, és ki sem alakítható) modellt másoknál jobban megközelítsék. ${ }^{33}$ Észre kell venni, hogy mind a releváns modell, mind az egyedi előrejelzések szintjén a torzítatlan becslések készítésére vonatkozó feltételezéssel egyszerre állítjuk magának a releváns modellnek, valamint a modellbecslés inputjait jelentő adatsoroknak az ismeretét. Ha ezek közül bármelyik is nem teljesül, a kapott becslések szisztematikus torzítást fognak tartalmazni. ${ }^{34} \mathrm{Az}$ elméleti paraméterek ismeretének és megismerhetőségének kérdéséről már ejtettünk szót, de néhány megjegyzést még hozzá kell füznünk - így az információk feletti rendelkezés problémájának tárgyalását kicsit későbbre halasztjuk.

Matematikai modellvizsgálatokra hivatkozva Benjamin Friedman amellett érvel, hogy még végtelen időhorizont esetén sem biztosított, hogy a gazdasági szereplők ténylegesen eljutnak a helyes modellhez, így várakozásaik nem lesznek racionálisak muth-i (erös) értelemben (B. Friedman 1979). Kanyarodjunk vissza az egyedi becslések hibájának sztochasztikus viszonyok melletti definíciójához:

$$
y_{t}-E_{t-1}\left(y_{t}\right)=x_{t}^{\prime}\left[\beta-E\left(b_{t-1}\right)\right]+\widehat{u}_{t} .
$$

Az egyenlet bal oldalán álló elörejelzési hiba csakis akkor lesz független a magyarázó változóktól, ha teljesül az, hogy $E\left(b_{t-1}\right)=\beta$, és így a hibák kizárólag a véletlen hatását tükrözik (vö. B. Friedman 1979:30). Másként pedig azt mondhatjuk, hogy az előrejelzési hiba csakis akkor lesz független a magyarázó változóktól, ha teljesül a paraméterbecslések torzítatlansága. Ha tehát $\beta-E\left(b_{t-1}\right) \neq 0$, nem lesz igaz, hogy a becslési hibák várható értéke zérus, ami csak akkor teljesülhetne, ha igaz lenne az, hogy $y_{t}-E_{t-1}\left(y_{t}\right)=\widehat{u}_{t}$ (hiszen a hibatag fehér zaj), ami viszont ekvivalens azzal, hogy $\beta=E\left(b_{t-1}^{t}\right)$, és így $x_{t}^{\prime}\left[\beta-E\left(b_{t-1}\right)\right]=0$. A modell paramétereinek torzított becslése számos tényezőre vezethető vissza: ilyen ok lehet például a függvényforma téves megválasztása. Ha helytelenül választunk lineáris függvényformát, a hibatag alakulása nem lesz független saját maga korábbi értékeitől, vagyis autokorreláció fog fellépni - ebben az esetben pedig nem lesz igaz az, hogy a hibatagokra vonatkozóan nem állnak rendelkezésre előzetes információk. Továbbá a becslések készítésekor hozzáférhető információk alapján a reziduum is - bizonyos korlátok között - elöre jelezhetővé válik. A modellparaméterek téves meghatározása azt is jelentheti, hogy némely fontos magyarázó változó becsült paraméterét a priori tévesen zérussal tesszük egyenlővé - ez az eset követ-

${ }^{33}$ Az esélyen jelen esetben a több és jobb minőségü adatsorokhoz való hozzáférést kell érteni. Jusson eszünkbe, hogy az egyes gazdasági szereplökröl professzionális szintü ökonometriai ismereteket feltételeztünk - ennek hiján persze a módszertani ismeretek hiánya is rontaná a megfelelö modell kialakításának esélyeit.

${ }^{34}$ Itt még egyszer érdemes felhívni a figyelmet a (hipotetikus) releváns elmélet, illetve az egyedi becslések megkülönböztetésére. Láttuk, hogy sztochasztikus folyamatok mellett az elméleti paraméterek megismerésére még elviekben sem nyílik lehetőség. A REH előzőekben adott értelmezése szerint a priori létezik tehát egy releváns modell, amely torzítatlan becslésekre képes, az egyedi szereplök által készített becslések pedig egytöl egyig az adatgenerálási folyamat torzítatlan becslései. 
kezményeit tekintve egyébként ekvivalens a releváns magyarázó változók kényszerü mellőzésével, amelyet hiányos információk okozhatnak. Ekkor a hibatag a kihagyott változók hatását is tükrözni fogja, vagyis annak alakulása a modellben nem szerepeltetett változók alapján előre jelezhető lesz, és a fellépő autokorreláltság miatt pedig a hibák jövőbeli alakulása a reziduumok múltbeli értékei alapján is közelíthető lesz - mindeközben pedig a modellben hagyott változók paraméterei is várhatóan torzítottak lesznek; az ortogonalitásra vonatkozó tétel tehát ismét megsérül. Mondhatnánk, hogy a releváns modell trail and error alapú keresésének esélyét e problémák tovább csökkentik, ha az nem volna eleve lehetetlen. Bár kétségtelen, hogy az egyedi becslések torzítatlansága - ha azt nem a mintha-érvelés alapján tételezzük fel - igen magas szintü technikai és információs követelményeken alapul.

$\mathrm{Az}$ adatok rendelkezésre állása tehát nem kevésbé fontos kérdés. A becslések szisztematikus torzítása emiatt még akkor is létrejöhet, ha egyébként teljesülne a releváns modell léte és a paraméterek értékeinek pontos a priori ismerete. Ahogy korábban már említettük, a gazdasági szereplők ebben az információk megszerzéséért folytatott versenyben nem indulhatnak egyenlő esélyekkel: léteznek könnyebben, mindenki számára hozzáférhető, illetve „bennfentes” (vagyis speciális) információk, amelyek egyaránt hatással lehetnek a kérdéses gazdasági változó időbeli lefutására -, ráadásul a teljes informáltság állapotába való eljutás költséghatékonysági alapon is megkérdőjelezhető. ${ }^{35} \mathrm{~A}$ jegybank által készített inflációs becslések például számos olyan információt tartalmaznak, amelyek az idősorok ismerete alapján nem sajátíthatók el; jellemző például a hazai gyakorlatból is ismert eset, amikor a modellek alapján adott becsléseket a szakértői konzultációk során megszerzett információk alapján módosítják. Az árak alakulására számos olyan tényező hat, amely a múltbéli adatokból nem következik: ha például a kiskereskedelmi élelmiszerforgalmazók versenyében néhány hónapon belül új résztvevő fog megjelenni. Erre vonatkozóan a már jelenleg is a piacon tartózkodó forgalmazók rendelkeznek információkkal (s esetleg előzetes külföldi példák alapján azt is sejtik, hogy az új szereplő milyen ár- és versenypolitikát fog folytatni), mindez már a jelenbeli, s a közeljövőre vonatkozó árazási döntéseiket is meg fogja határozni. Így, ha például az új szereplőtől azt várják, hogy a szokásosnál alacsonyabb árakkal igyekszik majd átírni a piaci részesedési viszonyokat, már a jelenlegi áremelkedési ütem is módosulni fog, vagyis a piacon tartózkodók igyekeznek visszafogni a drágulást, ezzel felkészülve az élesedő versenyre. Ha a központi bank ennek alapján módosítja a modellekből származó előrejelzéseket, nem tesz mást, mint racionálisan alakítja ki várakozásait. Meg kell jegyezni azt is, hogy általánosságban a jegybanki előrejelzések a különböző időtávokon más-más súlyokat adnak az egyes elörejelzési módszereknek. Rövid távon jól használhatók a szakértői becslések, vagyis ezek hatására a modellekből származó elörejelzések módosításra kerülnek, míg az időhorizont növekedésével a modellbecslések egyre nagyobb jelentőséget kapnak. Azt is észre kell venni, hogy az e kiegészító információkat nélkülöző piaci szereplők becslései el fognak térni a jegybank által adott elörejelzéstől, holott mindkettő racionális (gyenge értelemben legalábbis), hiszen azokat az információkat ténylegesen nem lehet figyelembe venni, amelyek nem ismertek az aktorok számára. ${ }^{36}$ Azt persze nem lehet feltételezni, hogy a szakértői

35 Mindez egyébként komoly érv az inflációs célkövetési rendszer müködése mellett, hiszen az aktorok számára gazdaságosabb lehet egy készen kapható modell-output felhasználása.

36 Barro és Fischer ehhez teljesen hasonló értelemben használja a várakozások racionalitásának fogalmát, hiszen racionálisnak tekintenek minden olyan elörejelzést, amely a rendelkezésre álló információk alapján a jövőbeli folyamatok optimális becslésének tekinthető, még akkor is, ha a piaci szereplő nem rendelkezik mindazzal az információval, amelyet a modellben felhasználnak (Barro - Fischer 1976:156). 
konzultációkat nélkülözni kényszerülő aktorok is rendelkeznek az így elsajátítható tudással, hiszen ha ez a tudás eleve rendelkezésre állna, a jegybanki elemzők - mint hétköznapi fogyasztók - maguk is tudatában lennének ezen információkkal. Így a szakértői egyeztetések feleslegessé válnának. Erre valójában nincs is szükség, hiszen még Muth definíciója sem írta elő a releváns modell (ennek helyettesítője ebben az esetben a jegybank által készített elörejelzés) és az egyes egyedi becslések egyformaságát. Az előzőek során elmondottakból azonban az is következik, hogy a jegybanki modell sem lesz torzítatlan, $s$ fokozottan igaz ez az egyedi becslésekre is.

\section{Következtetések: út az inflációs célkövetési rendszerig}

Érvelésünk az eddigiekben annak beláttatására irányult, hogy a releváns modell kialakításának lehetőségei korlátozottak, s így egy-egy makrogazdasági rendszert leíró teljes és tökéletes tudás legfeljebb kényelmes előfeltételezés lehet. Az elméleti paramétervektor ismerete még magas szintű ökonometriai eszközök birtoklása és a releváns magyarázó változók adekvát azonosítása mellett sem képzelhető el - még inkább igaz ez, ha a modellezők munkáját egyes információk elérhetetlensége is tovább nehezíti. Az elözőek során tehát alig észrevehetően bevezettünk egy fogalmat (vagy helyesebb talán jelenségnek nevezni). Eszerint a becslések torzitása nem független a modellezö által birtokolt információk mennyiségétől és minőségétöl. Ezt másként fogalmazva úgy mondhatnánk, hogy a becslések aszimptotikusan torzítatlanok a felhasznált információkra nézve, vagyis:

$$
\lim _{i \rightarrow i *} E(\widehat{\Theta})=\Theta
$$

ahol $\Theta$ az elméleti paraméter, $\widehat{\Theta}$ ennek empirikus becslése, az $i$ változó pedig a becslés készítésekor feldolgozott információk mennyiségét jelenti. Ha ez tart a teljes tudáshoz $\left(i^{*}\right)$, akkor az empirikus paraméterek egyre jobban és jobban meg fogják közelíteni az adatgenerálási folyamatban közreműködő elméleti paraméterek értékeit. Ehhez hasonlóan értelmezhetnénk a konzisztencia követelményét is:

$$
\lim _{i \rightarrow i *} P(\Theta-\varepsilon \leq \widehat{\Theta} \leq \Theta+\varepsilon)=1 \text {, minden } \varepsilon>0 \text { esetén. }
$$

A $R E H$ erős hipotézisének olyan (mérsékelt ${ }^{37}$ ) értelmezése is megadható az aszimptotikus torzítatlanság alapján, amelyben nem követeljük meg a releváns modelltől az elméleti paraméterek ismeretét - mindez persze azt jelenti, hogy feloldjuk az egyedi becslések torzítatlanságára vonatkozó feltételt. Az a gazdasági szereplő (pl. a monetáris hatóság), aki kellő mennyiségü és minőségű információ, illetve módszertani ismeret birtokában van, el tudja majd készíteni a kérdéses makrogazdasági rendszert leíró kvázi-releváns modellt (a felhasz-

37 E mérsékelt hipotézist határozottan meg kell különbözetni a REH gyenge hipotézisétöl, hiszen e mérsékelt hipotézis értelmében továbbra is a REH erös definíciójának körén belül mozgunk. 
nált információk növelésével tehát mindenképpen mérsékelni tudja a torzítás mértékét), és minél inkább központi szerepben van, annál nagyobb eséllyel tudja azt elfogadtatni majd a gazdaság többi szereplöjével (valójában nem teszünk tehát mást, mint lazítunk a feltételezéseken, és a kvázi-releváns modelltől követeljük meg azt - vagyis a puszta torzítatlanságot, nem pedig az elméleti paramétervektor ismeretét -, amit eddig az egyedi becslésektől vártunk el. Ha így az egyedi becslések torzítottak lesznek, nem lesz igaz az sem, hogy az egyedi becslések átlagát a releváns modell fogja jelenteni). Innen már csak egy lépés tehát az inflációs célkövetési rendszer sikeres bevezetésének lehetősége, hiszen a gazdasági szereplők, tapasztalva az információk feldolgozásába fektetett fáradozásaik haszontalanságát (hiszen szisztematikusan torzított becslések készitésénél többre nem voltak képesek), úgy fognak dönteni, hogy ehelyett a releváns modell outputjaihoz igazítják majd várakozásaikat. Így az egyedi aktorok várakozásai végső soron ismét torzítatlanok lesznek, bár passzivitás mellett. Ha ez nem teljesülne, a monetáris hatóság alkalmazhatná a megtévesztés politikáján alapuló output-szabályozás eszközét - ettől legfeljebb azért tartózkodna, mert célfüggvénye úgy van definiálva, hogy az e megtévesztést nem teszi szükségessé.

Láttuk, hogy a modellezési munka körülményeiből nagy valószínűséggel egyenesen következik az egyedi becslések torzítottsága, ha tehát a racionális várakozásokat az információra vonatkozó aszimptotikus torzítatlanság koncepciója alapján kívánjuk értelmezni, a megtévesztésen alapuló jegybanki politika kizárásához szükség lesz a jegybanki célfüggvény megfelelő kialakítására is. A REH gyengített, vagyis a kvázi-releváns modell outputjainak használatára épülő verziójából levezethető lesz az inflációs célkövetési rezsim müködése, a monetáris hatóság ugyanis kezében tartja a várakozások formálásának lehetőségét, az idő-inkonzisztens politika kerülése mellett tett elköteleződése azonban megakadályozza a potenciális trade-off-ok kiaknázását. Ám ha a REH Muth által szándékolt értelmü definícióját tekintjük, azt kell látnunk, hogy abban nem is maradna hely a fenti értelemben vett jegybank számára a várakozások befolyásolása terén, hiszen a racionálisan várakozó aktorok önállóan is torzítatlan becslések készítésére képesek.

Úgy tủnik tehát, hogy az aggregált egyedi becslések torzítottsága információs oldalról is belátható. Magától értetődő, hogy a készített becslések a felhasznált információknak valamely függvényei. Nem nehéz belátni azt, hogy vannak könnyen, mindenki számára hozzáférhető információk, s vannak - erre láttunk példát - olyanok is, amelyek gyakorlatilag bennfentes ismereteknek tekinthetők. Nézzünk egy példát. Tételezzük fel, hogy egy nemzetgazdasági rendszerben a gazdasági szereplőknek két csoportja különíthető el, akik legyenek - az előző példánál maradva - élelmiszeripari fogyasztók, valamint egy élelmiszeripari forgalmazó (az ágazatnak természetesen semmi jelentősége sincs az illusztráció szempontjából). Mind a fogyasztók, mind a kereskedők önálló gazdasági egységnek számítanak. Inflációs várakozásaikat a fogyasztók ebben a helyzetben kizárólag a múltbéli folyamatok alapján alakítják ki, míg a forgalmazó figyelembe veszi speciális ismereteit is, amely szintén releváns információ az árszínvonal alakulása szempontjából. A torzítatlanság azt jelenti, hogy az egyedi becslések úgy fogják körbe a későbbi tényadatokat, hogy az egyes becslések torzításai kioltják egymást - ez az állapot azonban csak véletlenül következhet be, hiszen a becslések készítésénél aggregált szinten körülhatárolható egy olyan információs kör, amely erősen felülreprezentált (vagyis igen nagy súllyal kerül számbavételre). Ha elhisszük, hogy a speciális (szűkebb körben hozzáférhető) információk birtokában lévő piaci szereplő is tudatában van a fogyasztók által birtokolt (múltbeli folyamatokra vonatkozó) ismereteknek, azt mondhatjuk, hogy az általa készített becslés jobban fogja közelíteni a későbbi tény- 
adatokat (illetve a kimenetek valószínűség-eloszlásának várható értékét), ám az aggregált torzítatlansághoz az kellene, hogy az összes többi (a példa szerint azonos módon, illetve azonos irányba torzított) becslés olyan módon legyen torzított, hogy ezek a fogyatékosságok összességükben kioltsák egymást, ez pedig nem lehetséges, éppen azért, mert a torzítások következetesen egy irányba mutatnak - sőt, kiegyenlítés helyett sokkal inkább arról lesz szó, hogy az aggregált módon értelmezett várakozások alá-, vagy felülbecsülik majd a tényadatokat. A speciális információkat is tartalmazó becslés ${ }^{38}$ fogyatékosságait kell az összes többinek ellensúlyoznia, hogy átlagosan torzítatlan becsléseket kapjunk, ugyanakkor semmiféle értelmes szabályszerüség nem szól amellett, hogy ezt a kikötést akár feltételezésként is elfogadhassuk. Aggregált torzítatlanság (vagyis az az állapot, amelyben az egyes becslések átlagaként a későbbi tényadat vagy elméleti paramétervektor áll elö) legfeljebb véletlenül alakulhat ki. Ha adódik is ilyen helyzet (amelyben tehát az aggregált becslések torzítatlanok lesznek), annak permanens működésére semmiképp sem lehet számítani. Torzított egyedi becslésekből tehát torzítatlan aggregált becslések aligha származhatnak - láttuk, hogy ezt végső soron maga Muth sem tagadta, hiszen definíciójában az információs készlet nagysága kiemelt jelentőséggel szerepel. Ez az információs szimmetria azonban csak nehezen tételezhető fel, hiszen számos tényező eredményezheti az egyedi várakozások torzítottságát. További problémát jelent, hogy a REH egyes feltételezései nem konzisztensek egymással, hiszen a torzítatlanság, illetve a várakozásképzés nem professzionális alapú tételezése kizárja egymást (és itt valójában a mintha-érvelés is cserbenhagyja az elméletet, hiszen hogyan lehetne megmagyarázni a keresztmetszeti véleménykülönbségeket, ha az aktorok várakozásai a releváns elmélethez hasonlóan képződnek), és empirikusan gyakorlatilag megoldhatatlan az elméleti paraméterek ismeretén alapuló releváns modell kalibrálása.

Mindezek nyomán tehát a REH Muth által adott erős definíciójától eljutottunk az inflációs célkövetési rendszerig. Ehhez csupán arra volt szükség, hogy belássuk: a mintha-érvelés alkalmazásán kívül nem tételezhetjük fel, hogy a gazdasági szereplők a jövőbeli folyamatok torzítatlan becsléseit képesek elöállítani. Azt is láttuk, hogy módszertani nehézségek miatt az elméleti paramétervektorra irányuló ismeret aligha szerezhető meg a szokásos trial and error módszer segítségével. Még ha el is fogadjuk, hogy létezhet kiemelkedő makromodellezési készség a gazdasági szereplők oldalán, az információkhoz való korlátozott hozzáférés miatt becsléseik így is torzítottak lesznek, lehetőséget teremtve a szisztematikus jegybanki megtévesztésre épülő politika számára. A REH itt bevezetett mérsékelt elmélete szerint a várakozások kielégítő torzítatlansága annak köszönhető, hogy a gazdasági szereplök átveszik a legjobban teljesítő (kvázi-releváns) modell outputjait, így végső soron teljesülni fog a modell és az aktorok várakozásainak egybeesése. Ennek híján az aktorok csak torzított becsléseket lennének képesek elöállítani, lehetőséget teremtve a szisztematikus anticiklikus jegybanki politika Ha a $R E H$ erős hipotézisének müködését annak mérsékelt elmélete szerint az inflációs célkövetés rendszerében értelmezzük, egy megtévesztésre vonatkozó tilalom fennállásával kell számolnunk: az elköteleződésre képes és hajlandó jegybank rögzítheti a várakozásokat, hiszen a várakozások irányításával nem szolgál rövid távú kibocsátás-maximalizálási célokat. Mivel az egyedi becslések torzítatlanságát (vagy másként: a torzítás lehető legnagyobb mértékủ hiányát) nem az egyedi modellezők teljesítménye okozza, a jegybanki megtévesztés hiánya csakis önkéntes elköteleződés eredménye lehet - ennek híján az inflációs célkövetési rendszer müködése kerülne veszélybe.

${ }^{38}$ Amely szintén nem a releváns, vagy kvázi-releváns modell. 


\section{Hivatkozások}

Arrow, Kenneth J. (1979): Egyensúly és döntés. Közgazdasági és Jogi Könyvkiadó, Budapest.

Barro, Robert J. - Fischer, Stanley (1976): Recent Developments in Monetary Theory. Journal of Monetary Economics, 2. sz., 133-167.

Begg, David K. H. (1982): The Rational Expectations Revolution in Macroeconomics - Theories and Evidence. Philip Allan, Oxford.

Berlin, Isaiah (1990): Négy esszé a szabadságról. Európa Könyvkiadó, Budapest.

Black, John (2002): Dictionary of Economics. Oxford University Press, Oxford.

Bryant, John (1983): A Simple Rational Expectations Keynes-type Model. The Quarterly Journal of Economics, augusztus, 525-528.

Cesarano, Filippo (1983): The Rational Expectations Hypothesis in Retrospect. The American Economic Review, március. 198-203.

Dickinson, D. G. - Driscoll, M. J. - Ford, J. L. (1982): Rational Expectations, Random Parameters and the Non-neutrality of Money. Economica, 241-248.

Elster, Jon (2001): A társadalom fogaskerekei. Osiris Kiadó, Budapest.

Erdős Tibor (1998): Infláció. Akadémiai Kiadó, Budapest.

Farkas Zoltán (2006): A racionális cselekvés, a társadalmi cselekvés és kölcsönhatás. Miskolci Egyetem, Miskolc. http://mek.oszk.hu/03900/03944/

Fischer, Stanley (1977): Long-Term Contracts, Rational Expectations, and the Optimal Money Supply Rule. The Journal of Political Economy, február, 191-205.

Friedman, Benjamin (1979): Optimal Expectations and the Extreme Information Assumptions of 'Rational Expectations' Macromodels. Journal of Monetary Economics, 23-41.

Friedman, Milton (1970): The Optimum Quantity of Money. Aldine Publishing Company, Chicago.

Friedman, Milton (1986): Infláció, munkanélküliség, monetarizmus. Közgazdasági és Jogi Könyvkiadó, Budapest.

Gerrard, Bill (1994): Beyond Rational Expectations: a Constructive Interpretation of Keynes's Analysis of Behaviour Under Uncertainty. The Economic Journal, március, 327-337.

Harasztosi Péter (2004): Racionális várakozások és a Monetáris Konszenzus. Fordulat, tavasz. 64-75.

Hoover, Kevin D. (1990): The New Classical Macroeconomics - A Sceptical Inquiry. Blackwell, Oxford.

Horváth László (2000): Monetarizmus. In: Alapmüvek, alapirányzatok. AULA, Budapest.

Hume, David (1994): A pénzröl. In: David Hume összes esszéi II. Atlantisz, Budapest, 43-56.

Kantor, Brian (1979): Rational Expectations and Economic Thought. Journal of Economic Literature, december, 1422-1441.

Keuzenkamp, Hugo A. (1991): A Precursor to Muth: Tinbergen's 1932 Model of Rational Expectations. The Economic Journal, szeptember, 1245-1253.

Mátyás Antal (1984): A polgári politikai gazdaságtan napjainkban. Kossuth Könyvkiadó, Budapest.

Mill, John Stuart (1980): A szabadságról - Haszonelvüség. Magyar Helikon, Budapest.

Mises, Ludwig von (1981): The Theory of Money and Credit. Liberty Classics, Indianapolis.

Muth, John F. (1961): Rational Expectations and the Theory of Price Movements. Economica, 3. sz., 315-335.

Pete Péter (2001): Bevezetés a monetáris makroökonómiába. Osiris Kiadó, Budapest.

Sargent, Thomas J. - Wallace, Neil (1975): „Rational” Expectations, the Optimal Monetary Instrument, and the Optimal Money Supply Rule. Journal of Political Economy, 2. sz., 241-254.

Shaw, G. K. (1984): Rational Expectations - An Elementary Exposition. Harvester Press, Brighton.

Várpalotai Viktor (2003): Dezaggregált költségbegyürüzés-alapú ökonometriai infláció-elörejelzö modell. Magyar Nemzeti Bank, Budapest.

Vigvári András (2004): Pénzügy(rendszer)tan. KJK-KERSZÖV, Budapest.

Visco, Ignazio (1984): Price Expectations in Rising Inflation. North-Holland, Amsterdam - New York Oxford.

Weeks, John (1998): A neoklasszikus közgazdaságtan kritikája. Aula Kiadó, Budapest. 
